\title{
Impact of Helicobacter pylori-Related Metabolic Syndrome Parameters on Arterial Hypertension
}

\author{
Jannis Kountouras ${ }^{1, *}$, Apostolis Papaefthymiou $1,2,3 \Subset$, Stergios A. Polyzos ${ }^{3}\left(\right.$, Georgia Deretzi ${ }^{4}$, \\ Elisabeth Vardaka ${ }^{5}$, Elpidoforos S. Soteriades ${ }^{6,7}$, Maria Tzitiridou-Chatzopoulou ${ }^{1,8} \mathbb{(}$, \\ Paraskevas Gkolfakis ${ }^{9,10}{ }^{\infty}$, Kyriaki Karafyllidou ${ }^{11}$ and Michael Doulberis ${ }^{1,3,12}(\mathbb{D}$
}

1 Second Medical Clinic, School of Medicine, Ippokration Hospital, Aristotle University of Thessaloniki, 54642 Thessaloniki, Greece; appapaef@hotmail.com (A.P.); mariatzitiridou@gmail.com (M.T.-C.); doulberis@gmail.com (M.D.)

2 Department of Gastroenterology, University Hospital of Larisa, 41110 Larisa, Greece

3 First Laboratory of Pharmacology, School of Medicine, Aristotle University of Thessaloniki, 54124 Thessaloniki, Greece; spolyzos@auth.gr

4 Multiple Sclerosis Unit, Department of Neurology, Papageorgiou General Hospital, 56403 Thessaloniki, Greece; gderetzi@gmail.com

5 Department of Nutritional Sciences and Dietetics, School of Health Sciences, International Hellenic University, 57400 Thessaloniki, Greece; evardaka@aqua.theite.gr

check for updates

Citation: Kountouras, J.;

Papaefthymiou, A.; Polyzos, S.A.;

Deretzi, G.; Vardaka, E.;

Soteriades, E.S.;

Tzitiridou-Chatzopoulou, M.;

Gkolfakis, P.; Karafyllidou, K.;

Doulberis, M. Impact of Helicobacter pylori-Related Metabolic Syndrome Parameters on Arterial Hypertension. Microorganisms 2021, 9, 2351.

https://doi.org/10.3390/

microorganisms 9112351

Academic Editor: Josette Raymond

Received: 1 October 2021

Accepted: 10 November 2021

Published: 14 November 2021

Publisher's Note: MDPI stays neutral with regard to jurisdictional claims in published maps and institutional affiliations.

Copyright: (c) 2021 by the authors. Licensee MDPI, Basel, Switzerland. This article is an open access article distributed under the terms and conditions of the Creative Commons Attribution (CC BY) license (https:// creativecommons.org/licenses/by/ $4.0 /)$.
6 Healthcare Management Program, School of Economics and Management, Open University of Cyprus, Nicosia 2252, Cyprus; elpidoforos.soteriades@ouc.ac.cy

7 Department of Environmental Health, Environmental and Occupational Medicine and Epidemiology (EOME), Harvard T.H. Chan School of Public Health, Boston, MA 02115, USA

8 School of Healthcare Sciences, Midwifery Department, University of West Macedonia, Koila, 50100 Kozani, Greece

9 Department of Gastroenterology, Hepatopancreatology and Digestive Oncology, Erasme University Hospital, 1070 Brussels, Belgium; pgkolfakis@med.uoa.gr

10 Department of Medical Oncology, Institut Jules Bordet, 1000 Brussels, Belgium

11 Department of Pediatrics, University Children's Hospital of Zurich, 8032 Zurich, Switzerland; kikh.karafyllidou@gmail.com

12 Division of Gastroenterology and Hepatology, Medical University Department, Kantonsspital Aarau, 5001 Aarau, Switzerland

* Correspondence: jannis@auth.gr

Abstract: Arterial hypertension is a risk factor for several pathologies, mainly including cardiocerebrovascular diseases, which rank as leading causes of morbidity and mortality worldwide. Arterial hypertension also constitutes a fundamental component of the metabolic syndrome. Helicobacter pylori infection is one of the most common types of chronic infection globally and displays a plethora of both gastric and extragastric effects. Among other entities, Helicobacter pylori has been implicated in the pathogenesis of the metabolic syndrome. Within this review, we illustrate the current state-of-the-art evidence, which may link several components of the Helicobacter pylori-related metabolic syndrome, including non-alcoholic fatty liver disease and arterial hypertension. In particular, current knowledge of how Helicobacter pylori exerts its virulence through dietary, inflammatory and metabolic pathways will be discussed. Although there is still no causative link between these entities, the emerging evidence from both basic and clinical research supports the proposal that several components of the Helicobacter pylori infection-related metabolic syndrome present an important risk factor in the development of arterial hypertension. The triad of Helicobacter pylori infection, the metabolic syndrome, and hypertension represents a crucial worldwide health problem on a pandemic scale with high morbidity and mortality, like COVID-19, thereby requiring awareness and appropriate management on a global scale.

Keywords: Helicobacter pylori; metabolic syndrome; atherosclerosis; non-alcoholic fatty liver disease; arterial hypertension; diet; inflammation 


\section{Introduction}

Arterial hypertension is one of the most important components of the metabolic syndrome (MetS) and represents a global major health burden with implications for individual and public health, as well as direct and indirect healthcare costs. It is a substantial factor for the development of atherosclerosis, with a high global incidence and prevalence that continues to increase and contributes to worldwide morbidity and mortality [1]. It constitutes a major risk factor for MetS-related cardiovascular disease and the leading cause of mortality related with MetS-associated chronic kidney failure, ischemic heart disease and stroke [2,3]. In 2015, a total of 1.13 billion adults had arterial hypertension worldwide [4]; this figure is predicted to increase to 1.56 billion by 2025 [5]. Notably, an estimated 7.7-10.4 million annual deaths are attributable to arterial hypertension [6,7].

Although the pathogenesis of arterial hypertension is not entirely understood, there is support for the idea that its pathogenesis predominantly consists of a noxious interplay among vascular, renal, neural, and hormonal mechanisms, of which increased activation of the sympathetic nervous system (SNS) and the renin-angiotensin-aldosterone system (RAAS) prevail [8]; RAAS dysregulation, including the systemic and brain RAAS, has been recognized as one of the main causes of several types of arterial hypertension [9]. RAAS overactivation also contributes to MetS-related obesity and cardiovascular morbidity and mortality $[10,11]$.

Specifically, potential causative agents of hypertension include the following (Table 1): (1) genetic factors [12]; (2) diet (particularly sodium and potassium intake, as well as western diet) [13-15]; (3) adiposity [16]; (4) hyperinsulinemia and insulin resistance (IR) [17]; (5) smoking [18]; (6) endothelial dysfunction linked with MetS [19], with excessive release of vasoconstrictive agents and defective secretion of smooth-muscle relaxing mediators, such as nitric oxide [20]; (7) gut microbiota dysbiosis connected with MetS [15,21-23]; (8) inflammatory mechanisms, including pro-inflammatory cytokines and chemokines overexpression, cell infiltration and oxidative stress-all induced by excessive immune system stimulation - that are strongly upregulated in the hypertensive setting [24,25]; (9) innate and adaptive immune system involvement $[25,26] ;(10)$ nonalcoholic fatty liver disease (NAFLD), also closely associated with MetS [27]; (11) MetS-related brain neurodegenerative disorders, through disruption to the blood-brain barrier, triggering neuroinflammation, and exacerbation of amyloid disorders and decreased function of the cerebral blood vessels, including reduced cerebral blood flow, altered brain autoregulation, and compromised neurovascular coupling [28-31]; (12) MetS-related cancer development [32,33].

Likewise, Helicobacter pylori (H. pylori) infection is a global public health problem [34], with higher burdens in the developing nations [34,35], mostly owing to low socio-economic levels, and the potential drinking of contaminated water. H. pylori infection is very common with a mean global prevalence of $58 \%$, partly due to immigrants coming from countries with a high prevalence of $H$. pylori infection [36]. A rather recent global systematic review on the prevalence of $H$. pylori estimated that approximately 4.4 billion individuals were infected from H. pylori in 2015 [34]. Several issues, including age, gender, number of family members and financial status, education, lifestyle, health condition, and area of residence could affect the prevalence of $H$. pylori in different populations [34].

Beyond H. pylori-related gastric pathologies [37], $H$. pylori infection is also associated with MetS-related systemic pathologies, especially cardio-cerebrovascular, and neurodegenerative diseases, the endpoints of MetS [38-43]. It is important to note that almost all the aforementioned potential causative agents involved in the pathogenesis of arterial hypertension are also involved in the pathophysiology of $H$. pylori-related pathologies [36,38-40,42-55].

In this study, we aimed to investigate the potential impact of $H$. pylori-related MetS parameters on arterial hypertension, since the triad of $H$. pylori infection, MetS, and hypertension currently represents a fundamental worldwide health problem on a pandemic scale with high morbidity and mortality, like COVID-19, thereby requiring awareness and appropriate management on a global scale [56,57]. 
Table 1. Synopsis of potential etiologic agents of MetS-related arterial hypertension.

\begin{tabular}{|c|c|c|}
\hline Category & Comment & References \\
\hline Genetic factors & ATP2B1 gene polymorphisms rs2681472 and rs17249754 & [12] \\
\hline Diet & High $\mathrm{Na}^{+} / \mathrm{K}^{+}$intake and western-type of diet & [13-15] \\
\hline Adiposity & Activation of the SNS and RAAS, and sodium retention & [16] \\
\hline Smoking & Mainly via stimulation of the SNS & [18] \\
\hline $\begin{array}{l}\text { Endothelial dysfunction } \\
\text { linked with MetS }\end{array}$ & $\begin{array}{l}\text { Excessive release of vasoconstrictive agents and defective } \\
\text { secretion of smooth-muscle relaxing mediators }\end{array}$ & [17] \\
\hline Gut microbiota dysbiosis & $\begin{array}{l}\text { Via production, modification, and degradation of } \\
\text { microbial-derived bioactive metabolites }\end{array}$ & {$[15,21-23]$} \\
\hline Inflammatory mechanisms & $\begin{array}{l}\text { Overstimulated immune system induction of pro } \\
\text {-inflammatory cytokines and chemokines overexpression, } \\
\text { cell infiltration and oxidative stress }\end{array}$ & {$[24,25]$} \\
\hline NAFLD linked with MetS & $\begin{array}{l}\text { Mainly but not exclusively with hyperinsulinemia-insulin } \\
\text { resistance }\end{array}$ & [27] \\
\hline $\begin{array}{c}\text { MetS-related brain neurodegenerative } \\
\text { disorders }\end{array}$ & $\begin{array}{l}\text { Disruption of blood-brain barrier, triggering } \\
\text { neuroinflammation and amyloid disorders and decreasing } \\
\text { the function of the cerebral blood vessels, including reduced } \\
\text { cerebral blood flow, altered brain autoregulation, and } \\
\text { compromised neurovascular coupling }\end{array}$ & [28-31] \\
\hline MetS-related cancer development & $\begin{array}{l}\text { Arterial hypertension displays a two-fold increased risk for } \\
\text { GC development }\end{array}$ & {$[32,33]$} \\
\hline
\end{tabular}

MetS, metabolic syndrome; NAFLD, nonalcoholic fatty liver disease; GC, gastric cancer; RAS, renin-angiotensin system; SNS, sympathetic nervous system.

\section{H. pylori-Related Arterial Hypertension}

Generally, pathogen infection could be one of the inflammatory triggering factors that is connected with the incidence and development of arterial hypertension, including abnormal systolic and/or diastolic pressure [58,59]. Chronic stimulation of inflammatory reactions owing to bacterial infection in the gastrointestinal tract generates induction of MetS-related dyslipidemia, triggers release of C-reactive protein (CRP), escalates blood leukocytes and MetS-related homocysteine, increases the concentrations of MetS-related fibrinogen, induces hypercoagulability, stimulates immune cross-reactivity, and rises proinflammatory cytokines and other cytotoxic agents. This intense rise in the release of diverse pro-inflammatory and inflammatory mediators disturbs blood vessel motility and induces endothelial dysfunction, which results in the obstruction of arteries, thereby leading to arterial hypertension and coronary artery disease. In this regard, chronic H. pylori infection leads to disturbed immune reactions, which ultimately contribute to arterial hypertension and cardiovascular abnormalities, including coronary artery disease. Specifically, relative data indicate that $H$. pylori is positively correlated with the risk of arterial hypertension [60-62]. As a consequence, H. pylori-positive hypertensive patients display significantly higher arterial blood pressure than that of hypertensive patients without the infection [62]. Moreover, H. pylori eradication has been reported to improve arterial hypertension [63,64].

The mechanisms involved in the pathophysiology of $H$. pylori-related arterial hypertension appear to be multifactorial, including diet, inflammatory processes, and MetS-related parameters (Figure 1). 


\section{Proposed impact of $\boldsymbol{H}$. pylori infection on arterial hypertension}

\section{H. pylori related MetS parameters}

Q. and arterial hypertension

- H.pylori infection - IR

- H.pylori infection $\uparrow$ monocytes

$\&$ fibroblasts in atheromas

- H.pylori infection triggers $\quad$ L 30 abnormal metabolism \& dyslipidemia

- Bariatric patients with H.pylori infection are associated with arterial hypertension, IR and gastric premalignant lesions

- H.pylori infection eradication $\downarrow$ TC, TG, CRP, fibrinogen, LDL-C, $\& \uparrow$ HDL-C

- GC \& arterial hypertension $\rightarrow$ common inoscitol triphosphate pathway

- arterial hypertension $\rightarrow$

$2 \mathrm{x}$ risk of GC

\section{H. pylori related \\ diet and arterial hypertension}

- $\uparrow$ Salt consumption favors H.pylori colonization

- $\uparrow$ Salt consumption $\downarrow$ H. pylori-resistant gland mucous cell mucin

- Akita (Japan) $\uparrow$ Salt consumption \& $\mathbf{7 0} \%$ H.pylori infection

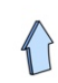

\section{H. pylori related inflammation}

and arterial hypertension

- H.pylori infection $\uparrow$ inflammatory mediators: TNF- $\alpha$, IL-1, IL-6, IL-8, IFN- $\gamma$, fibrinogen, thrombin, intracellular/vascular (cell) adhesion molecules $\rightarrow$ damage the vascular walls $\rightarrow$ arteriosclerosis

- H.pylori associated CagA protein \& cross-reactivity with heat shock proteins $\rightarrow$ damage the vascular walls $\rightarrow$ arteriosclerosis

- H.pylori infection $\uparrow$ fibrinogen \& inflammatory mediators $\rightarrow$ $\uparrow$ peripheral vascular tension but not cardiac output $\rightarrow$ diastolic arterial hypertension

Figure 1. Proposed pathogenetic mechanisms, owing to $H$. pylori infection-related MetS, that may contribute to arterial hypertension. CagA, cytotoxin-associated gene A; CRP, C-reactive protein; HDL-C, high-density lipoprotein cholesterol; $H$. pylori, Helicobacter pylori; IL, interleukin; IR, insulin resistance; LDL-C, low-density lipoprotein-cholesterol; MetS, metabolic syndrome; TC, total cholesterol; TG, triglycerides; TNF, tumor necrosis factor.

\subsection{H. pylori and Mets-Related Diet and Arterial Hypertension}

High salt consumption can cause the development of arterial hypertension $[65,66]$. Focusing on a $H$. pylori-related diet, high-salt consumption, as a recognized risk factor for arterial hypertension, also favors $H$. pylori colonization [67-69]; high salt intake could stimulate the gastric mucosa and make it susceptible to H. pylori infection [68]. Indeed, experimental data in mice have revealed that high-salt consumption facilitates the development of $H$. pylori colonies [68]. Likewise, high-salt intake increases the surface mucous cell mucin with an affinity to $H$. pylori, reduces the H. pylori-resistant gland mucous cell mucin, and injures the gastric mucosal gel layer [69]. As additional evidence, the 1991 EUROGAST study, by investigating worldwide H. pylori infection rates, reported that the Akita area in Japan had the highest incidence of H. pylori infection (70\%) [67]. Remarkably, Akita is located in the Tohoku region, where the diet is particularly high in salt compared to the other regions of Japan. The high H. pylori infection incidence in Akita, a developed region with raised standards of hygiene, indicates an association between $H$. pylori infection rates and high-salt diets [70]. Thus, the incidence of arterial hypertension in a region with a high-salt diet might be closely connected to $H$. pylori infection, though this may also depend on the degree of hygiene and sociocultural parameters [71,72].

It is important to note that, in relation to salt in the diet, there are two forms of hypertensive patients: salt-sensitive, as in the case of $H$. pylori infection, in whom blood pressure rises with high salt intake; and salt-resistant, whose blood pressure does not increase with salt intake (Figure 2) [73-75]. Salt-sensitive patients display impaired sodium 
excretion through the kidneys, which results in body salt retention, augmented circulating blood volume, increased cardiac output, and eventually enhanced peripheral vascular resistance, leading to arterial hypertension [73-77]. In order to compensate the expanded intravascular volume, renal and peripheral vascular resistance are reduced, renal blood flow (RBF) rises, and renal sodium excretion increases in salt resistance. Nevertheless, the decline in peripheral vascular resistance with a high-salt diet is absent in salt-sensitive patients, a phenomenon that is connected with compromised vascular endothelial function and abnormally enhanced vasoconstrictor reactions in vascular smooth muscle cells [78,79]. Elements that affect renal sodium absorption, and therefore salt-sensitive arterial hypertension, include the aforementioned RAAS [80] angiotensin II [81] aldosterone, as well as the aforementioned SNS [82,83]. Angiotensin II induces sodium retention by increasing tubular sodium reabsorption [81] and reducing RBF [84]. Experimentally increased aldosterone, in aldosterone-treated animal models [85], and obesity [86] appear to stimulate sodium reabsorption from the epithelial sodium channel in the distal tubule through the activation of mineralocorticoid receptors during salt intake, leading to fluid retention and finally to salt-sensitive arterial hypertension. It is important to note that high salt consumption appears to be a risk factor for MetS; several lifestyle elements are closely related with MetS, including a high-salt diet [87-89].

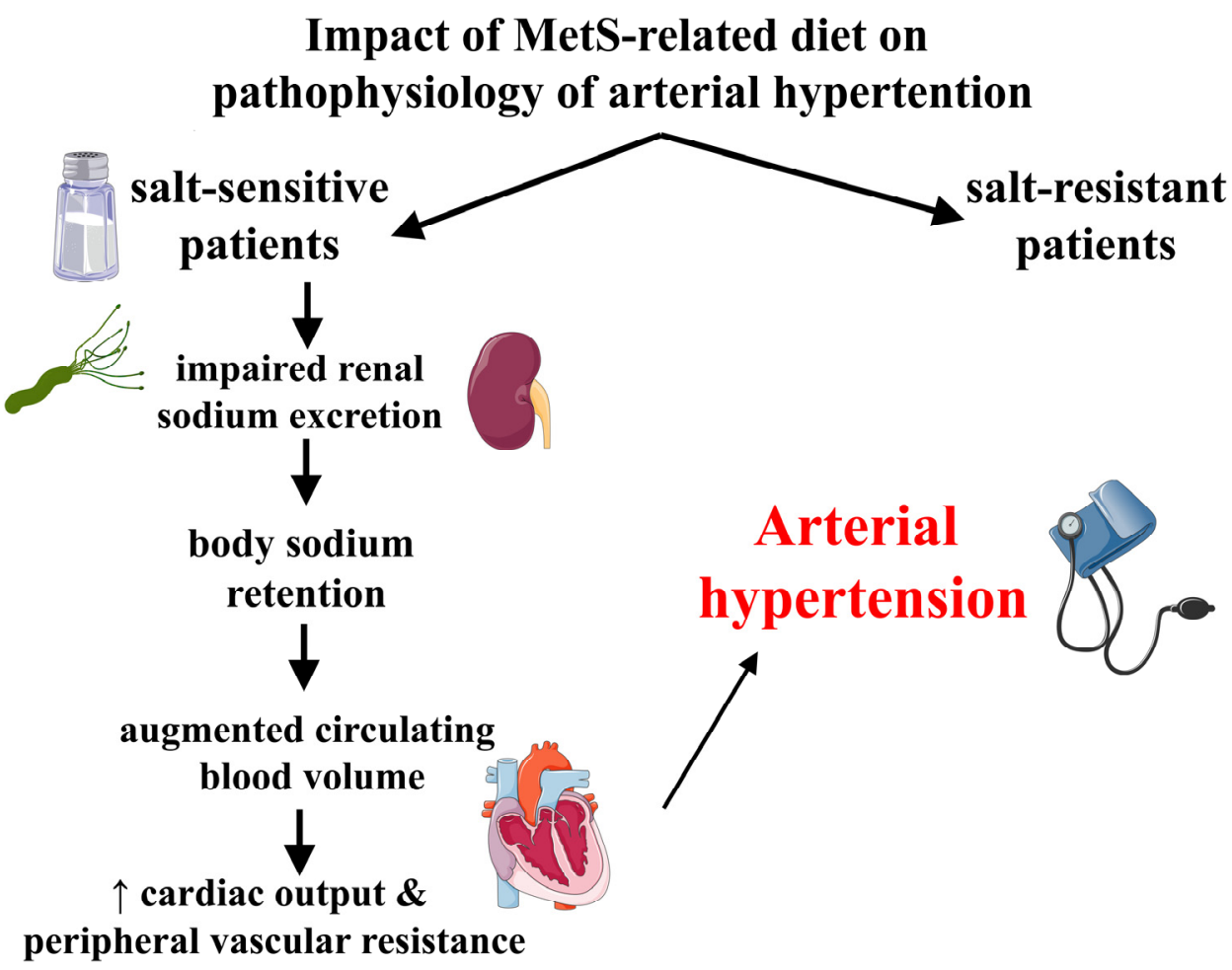

Figure 2. Simplified pathogenetic approach of diet (i.e., salt) impact on arterial hypertension. Patients with Helicobacter pylori infection belong also to the salt-sensitive category.

\subsection{H. pylori-Related MetS-Induced Inflammation and Arterial Hypertension}

Inflammatory processes are an important feature of MetS components; obesity, dyslipidemia, IR, and atherosclerosis are all closely connected with inflammatory processes [90,91].

Focusing on $\mathrm{H}$. pylori-related inflammatory processes, chronic inflammation due to H. pylori infection [46] activates a variety of mediators (Table 2) that have been linked to MetS-related endothelial cell dysfunction [19,92]. Indeed, H. pylori increases the levels of inflammatory mediators, such as MetS-related tumor necrosis factor (TNF)- $\alpha$, interleukin (IL)-1, IL-6, IL-8, interferon (IFN)- $\gamma$, fibrinogen, thrombin, intercellular adhesion molecule, and vascular cell adhesion molecule; these MetS-related inflammatory mediators directly or indirectly damage the vascular walls, thereby triggering atherosclerosis $[39,93-96] ;$ H. pylori- 
mediated inflammation has been linked to atherosclerosis [97]; and the aforementioned inflammatory mediators have been involved in the pathophysiology of MetS-related arterial hypertension $[98,99]$.

Specifically, CagA (cytotoxin-associated gene A) is a critical $H$. pylori virulence factor connected with a greater inflammatory response $[100,101]$ and H. pylori-related CagA could especially be involved in the development of atherosclerosis [102]; by introducing polymerase chain reaction (PCR), H. pylori DNA has been detected in the atherosclerotic plaques of patients with severe coronary artery disease, and $H$. pylori infection accompanying the expression of CagA proteins is significantly connected with coronary artery disease. Coronary artery disease patients with CagA display more extensive damage of the coronary artery lumen and more frequently post-percutaneous transluminal coronary angioplasty (PTCA) with stent insertion re-stenosis of the coronary artery; and a H. pylori eradication regimen improves the reduction in the coronary artery lumen in these post-PTCA patients, possibly owing to the reduction of $H$. pylori pro-inflammatory cytokine release and the attenuation or elimination of $H$. pylori-induced chronic inflammatory prosses [102]. It appears that the antibodies against CagA can directly cross-react with the surface antigen of the blood vessel wall [103], induce lymphocyte proliferation, and provoke the host to release several pro-inflammatory agents, such as the aforementioned IL-1, TNF- $\alpha$, IL-1, fibrinogen, and CRP [104,105]; as stated, such pro-inflammatory mediators are also related with MetS [106]. The subsequent inflammatory response increases the number of white blood cells and CRP concentrations in the circulation, triggers inflammation of the arterial wall, ultimately leading to vascular endothelial cell injury and dysfunction, smooth muscle cell proliferation, and atherosclerosis accompanied by arterial hypertension [107]. The existence of common epitopes, between the H. pylori CagA antigens and some peptides expressed by endothelial cells and smooth muscle cells is a phenomenon known as molecular mimicry. Therefore, in patients with a predisposition for arterial hypertension, the CagA antibodies could interfere with smooth-muscle cell function, thereby inducing arterial hypertension. However, this postulation remains to be elucidated. Of note, as in the case of CagA, H. pylori-induced vacuolating cytotoxin A (VacA) is also connected with a gastric inflammatory response, thereby contributing to gastric carcinogenesis. Moreover, VacA exhibits chemotactic activities in the bone marrow-derived mast cells and stimulates bone marrow-derived mast cells to induce proinflammatory cytokines that damage the bloodbrain barrier [49]. Furthermore, VacA promotes intracellular survival of the bacterium and activated monocytes (possibly infected with $H$. pylori due to defective autophagy, resulting in H. pylori replication in autophagic vesicles) might access the brain owing to blood-brain barrier disruption (the Trojan horse theory), thereby contributing to H. pylori-related MetS brain pathologies [45].

More specifically, the mechanism linked with chronic inflammation-the antigen cross-reactivity of $H$. pylori with epitopes-triggers an autoimmune response leading to inflammatory vascular endothelial damage [108], which is a feature of MetS, predisposing to MetS-related ischemic disorders [19]. Essentially, an autoimmune response, which involves cross-reactivity between CagA antibodies and vascular wall antigens, signifies that these antibodies may contribute to the activation of inflammatory cells within atherosclerotic lesions. Moreover, antigenic cross-reactivity between human heat shock proteins and $H$. pylori has been connected with coronary artery calcification and atherosclerosis, accompanied by arterial hypertension $[109,110]$.

Furthermore, atrophic gastritis owing to $H$. pylori infection with or without MetS induces vitamin B12 and folic acid deficiency, which results in hyperhomocysteinemia with subsequent damage to the vascular endothelial cells [111,112]; H. pylori-induced chronic gastritis can result in vitamin B12 and folate malabsorption, leading to methylation by 5- methyl-tetrahydrofolic acid failure and, hence, homocysteine accumulation. Hyperhomocysteinemia is a potent contributor to vascular disorders [111], an independent risk factor for MetS-related atherosclerosis [113], and a risk factor for arterial hypertension [114]. Specifically, homocysteine inhibits the secretion of nitric oxide by endothelial cells and trig- 
gers thromboxane-mediated platelet aggregation and vasoconstriction; it causes endothelial cell injury, promotes smooth muscle cell proliferation, and attenuates the protective effect of endothelial cell-derived relaxation agents [115]; and hyperhomocysteinemia, hyperfibrinogenemia, and high lipoprotein-a (a low density lipoprotein-like particle which contains the plasminogen homologue apo(a) disulfide-bound to apo B), as three 'non-conventional' coronary artery disease risk factors, may promote the occurrence of atherosclerosis and sequelae, including arterial hypertension [116].

It is important to note that diastolic blood pressure mostly depends on peripheral resistance, whereas systolic blood pressure predominantly depends on cardiac output. Patients with $H$. pylori infection display higher concentrations of MetS-related fibrinogen, an indicator of vascular inflammation that inhibits the production of nitric oxide and nitric oxide synthase (NOS) from the vascular endothelium, leading to vasoconstriction and augmented peripheral vascular tension [117]. The elevated concentrations of fibrinogen and inflammatory cytokines mentioned above in $H$. pylori-infected subjects result in high peripheral vascular tension but not cardiac output, which may explain, at least partly, why H. pylori infection was reported to be associated with diastolic blood pressure but not systolic blood pressure in some studies [118]. Of note, fibrinogen is a risk factor for hypertension, and its levels predict acute coronary and ischemic vascular events; moreover, they are higher in patients with future ischemic stroke development than those without [119-121]. Finally, H. pylori increases ammonia in the intestine and the accompanying intestinal spasms can impair absorption within the digestive tract, thus leading to enhanced reabsorption of sodium via the kidneys, causing arterial hypertension [63].

Table 2. Proposed pathogenetic mechanisms of H. pylori and MetS-induced inflammation on arterial hypertension.

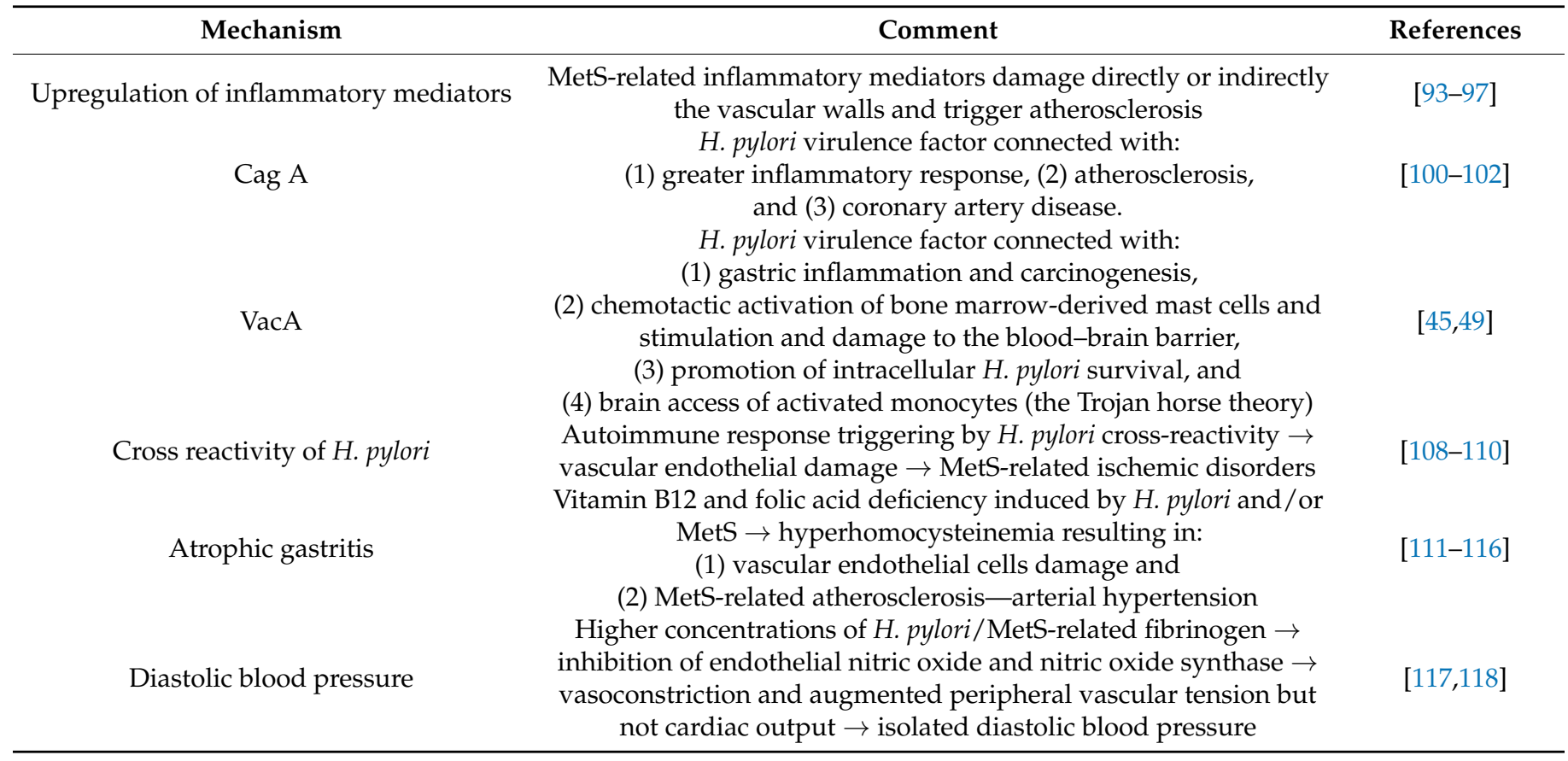

CagA, Cytotoxin-associated gene A; H. pylori, Helicobacter pylori; MetS, metabolic syndrome; VacA, vacuolating cytotoxin A.

\subsection{H. pylori-Related MetS Parameters and Arterial Hypertension}

Regarding H. pylori-related MetS parameters, H. pylori infection is a potential contributor to IR, the major underlying mechanism responsible for MetS [46], which also plays an important role in the pathogenesis and progression of arterial hypertension-triggered target organ injury [122,123]. MetS contributes to an increased risk of developing atherosclerosis [124], and, in this respect, invasion of H. pylori leading to atheroma has been detected by introducing PCR [102,125]]. Likewise, direct H. pylori colonization in the arterial walls has been observed [126]. Moreover, $H$. pylori reacts with monocytes and stimulates fibroblast 
proliferation in atheroma [127]. Thus, H. pylori has been associated with MetS-related atherosclerosis via a variety of mechanisms, thereby potentially triggering arterial hypertension. H. pylori infection might independently be involved in atherosclerosis and arterial hypertension via mechanisms distinct from the conventional causes of atherosclerosis, such as the three non-conventional coronary artery disease risk factors-homocysteine, fibrinogen, and lipoprotein(a) $[39,111,128]$.

MetS-related dyslipidemia is also linked with arterial hypertension [129], and, in this regard, chronic H. pylori infection can trigger abnormal lipid metabolism of the host including, besides lipoprotein(a) [128], low-density lipoprotein cholesterol (LDL-C), highdensity lipoprotein cholesterol (HDL-C), and total cholesterol (TC) $[130,131]$. Likewise, $H$. pylori inflammatory cytokines involved in MetS-related arterial hypertension appear to alter lipid profiles. TNF- $\alpha$ inhibits the action of lipoprotein lipase, and transfers lipids from the adipose tissue, so that the concentrations of triglycerides (TG) in the circulation increase, whereas the concentrations of HDL-C reduce [132]. Moreover, IL-6 and TNF- $\alpha$ increase liver cholesterol production by affecting the expression of 3-hydroxy-3-methyl glutaryl coenzyme A reductase gene, and inhibit cholesterol hydroxylase to decrease liver cholesterol catabolism [133]. In contrast, $H$. pylori eradication significantly decreases the concentrations of TC, TG, CRP, fibrinogen, and LDL-C, whereas it increases the concentrations of HDL-C $[134,135]$. Therefore, eradication of $H$. pylori infection reduces the occurrence of dyslipidemia, thereby potentially preventing the occurrence of MetS-related cardiovascular disease accompanied by arterial hypertension. Beyond dyslipidemia and arterial hypertension, $H$. pylori eradication also ameliorates other MetS-related parameters, such as body mass index (BMI) [136], IR [137], total oxidant status [138,139], and fibrinogen, an independent risk factor for cardiovascular disease [39]. Focusing on BMI, some other investigators reported that $H$. pylori eradication seems to restore ghrelin by increasing gastric ghrelin secretion, leading to increased plasma ghrelin levels, increased appetite and a rise in BMI, though a causative relationship between $H$. pylori-connected serum ghrelin decline and food intake and obesity has not been established. Since other data indicate that plasma ghrelin levels are lowered by following a H. pylori eradication regimen, further research is needed to clarify this issue.

Interestingly, recent data indicate that MetS-related sarcopenia, H. pylori infection, dyslipidemia, arterial hypertension, diabetes mellitus, smoking, alcohol consumption, and diet (salty and/or spicy diets) are associated with precancerous gastric mucosa lesions, including gastric atrophy, intestinal metaplasia, and dysplasia [140]. In this regard, MetS is associated with malignances, including H. pylori-related upper and lower gastrointestinal tract cancers, and besides other MetS-related parameters, arterial hypertension could be a key parameter $[46,141,142]$. Biochemical reactions induced by dysregulated MetS parameters, including arterial hypertension, affect the host's general condition and organ-specific microenvironment, leading to increased cancer recurrence and mortality [141]. Patients with arterial hypertension show a two-fold increased risk for gastric cancer (GC) development. Both arterial hypertension and GC may share a biochemical pathway of elevated inositol triphosphate and cytosolic calcium that could contribute to the pathogenesis of arterial hypertension and gastric carcinogenesis. Moreover, arterial hypertension is frequent in survivors of malignancies, and management of preexisting or incident arterial hypertension in these patients is crucial to reducing the risk of heart failure and other cardiovascular diseases [143]. Remarkably, recent data indicate that bariatric patients with H. pylori infection display significantly higher than baseline rates of the mentioned gastric pre-malignant lesions, including gastric atrophy and intestinal metaplasia accompanied with IR and arterial hypertension [144].

In line with the latter results, other investigators reported that bariatric patients also exhibit baseline occurrence of MetS-related parameters, such as arterial hypertension, dyslipidemia, IR, and even significant cyclooxygenase-2 (COX-2) induction. In contrast, bariatric surgery has been shown to decrease the magnitude of MetS-related comorbidities, such as arterial hypertension and dyslipidemia, and even remission of type 2 diabetes 
mellitus by normalizing peripheral insulin sensitivity and increasing pancreatic beta-cell sensitivity to glucose [145].

In this context, COX-2 also appears to be implicated in MetS components, including hypertension-related carcinogenesis [145]. It is mutagenic and tumorigenic in vitro, is frequently overexpressed in multiple malignant cells, and is associated with increased invasiveness and poor prognosis of tumors, including $\mathrm{H}$. pylori-related upper and lower gastrointestinal tract malignancies $[46,146]$. H. pylori-induced COX-2 overexpression enhances prostaglandin synthesis, which has been proved to promote the development, proliferation, and metastasis of cancer cells [146]. On the other hand, although COX-2 selective inhibitors attenuate inflammation and suppress oncogenesis, their clinical use is connected with potential side effects, most remarkably those within the cardio-cerebrovascular system, including arterial hypertension, myocardial infarction, and stroke [147]. Specifically, H. pylori induces an immune response via COX-2 stimulation, which increases the production of prostaglandin and nitric oxide [112], and the H. pylori cell wall lipopolysaccharide (LPS) triggers Toll-like receptor-4, which stimulates secondary mediators, including mitogen-activated protein kinase, extracellular-signal-regulated kinase, c-Jun N-terminal kinase, and c-p38 kinase, and further stimulates NOS and COX-2 gene expression [148,149]. This immune reaction to LPS might increase the risk of atherosclerosis [150]. COX-2 has been connected with pro-inflammatory/pro-atherogenic mechanisms, owing to its overexpression in monocyte-derived macrophages, existing in the atherosclerotic lesions [151]. Likewise, COX-2 expression may play a role in the progression of atherosclerosis and in the induction of plaque rupture [152]. Myocardial infarction and stroke are direct outcomes of atherosclerotic plaque rupture induced by prostaglandin-E2-dependent matrix-degrading metalloproteinases [153].

Regarding MetS-related arterial hypertension, combined arterial hypertension and atherosclerotic plaques might raise the risk of cardio-cerebrovascular severe events and mortality [154]. COX-2 is the principal source of intravascular reactive oxygen species creation, and, in arterial hypertension and diabetes, this seems to be the result of an interaction between COX-2-induced prostaglandins, lower activity of oxidase, RAAS, nicotinamide adenine dinucleotide phosphate, and bone morphogenic protein 4 , as a concentrated pathophysiological cascade in stimulating and preserving endothelial dysfunction $[155,156]$. Moreover, in patients with arterial hypertension, alterations in IL-12, IL-23, IL-27, IL-35, and IL-37 concentrations are connected with the development of carotid atherosclerotic plaque $[157,158]$. All aforementioned cytokines are also associated with $H$. pylori infection [159-162].

\subsection{H. pylori and MetS-Related NAFLD and Arterial Hypertension}

NAFLD, as the hepatic component of MetS, is associated with H. pylori infection, which appears to contribute to its development and progression [53]. Recent data indicate that $H$. pylori infection is connected with IR and augmented intestinal permeability, which could contribute to the development of NAFLD [163]; and active H. pylori infection is independently positively associated with the severity of nonalcoholic steatohepatitis (NASH) and fibrosis, findings suggesting probable clinical implications [53]. In this regard, among patients with NAFLD, the prevalence of arterial hypertension varies from $40-70 \%$ and relative studies have shown that NAFLD is strongly related to augmented risk of incident arterial prehypertension and hypertension [164,165]. Likewise, in the last few years, numerous cross-sectional studies have shown that the occurrence and severity of NAFLD are connected with augmented blood pressure and the occurrence of arterial prehypertension and hypertension $[166,167]$. Moreover, two- to three-fold rise in the incidence of arterial hypertension was confirmed in relative prospective epidemiological reports in France and Germany, after observational periods of nine and five years, respectively $[168,169]$. In addition, relevant data from Finland indicated that, among the hypertensive or normotensive participants, 24-h daytime and night-time systolic or diastolic blood pressure were significantly higher among participants with hepatic steatosis 
than without (estimated by ultrasound), while this association at a non-dipping status was marginally non-significant [170]. Ultrasonography revealed fatty liver more often when non-dipping or reverse dipping was found in 24-h ambulatory blood pressure monitoring in a group of hypertensive patients, and baroreceptor sensitivity was decreased with augmented blood pressure variability among patients with NAFLD [171,172].

Cytokeratin (CK)-18 is a well-known marker of hepatocellular-specific apoptosis with its additional potential value as a noninvasive indicator in predicting the severity of inflammation, steatosis, and fibrosis [173]. CK-18 is not normally found in vascular smooth muscle, but is highly expressed during the development of atherosclerotic plaques and has been shown to be elevated in hypertensive patients with NAFLD [174]. Indications are available displaying correlations of CK-18 with blood pressure, thus implying its crucial role in the pathophysiology of such disorders [174,175]. Specifically, CK-18 is an intermediate filament, the cleavage of which is an early event during apoptosis following activation of effector caspases and its immunoreactivity is significantly higher in the foveolar epithelium of $H$. pylori-positive gastritis compared with both $H$. pylori-negative gastritis and controls; higher expression of CK-18 in the foveolar epithelium is noticed in patients with CagA positive H. pylori-induced gastritis [176]. Furthermore, associations between liver enzymes, including serum aspartate aminotransferase, alanine aminotransferase, and gamma-glutamyl transferase and hypertension are well established. Likewise, several studies have reported positive associations between these enzymes and arterial hypertension in NAFLD [177]. Apparently, NASH associated with active H. pylori infection is characterized by increased levels of the aforementioned liver function tests [53].

The following proposed mechanisms (Table 3) appear to be involved in the pathophysiology of H. pylori and MetS-related NAFLD on arterial hypertension:

Hypertension 1. H. pylori and MetS-related NAFLD may promote arterial hypertension by inducing systemic inflammatory processes.

The liver, as an immunological organ with a distinctive tissue structure and cellular composition, comprising abundant Kupffer cells (residential macrophages) and immune cells, can provoke secretion of cytokines to defend against invading microorganisms and environmental challenges and release them into systemic circulation, thereby inducing systemic inflammation [178]. Correspondingly, recent clinical data showed that patients with NAFLD had significantly compromised cardiac and autonomic function, and, in particular, the raised levels of TNF- $\alpha$ and CK-18 (as markers for liver injury) in NAFLD patients were independently connected with augmented sympathetic activity and reduced parasympathetic activity [179]. Moreover, NAFLD has been reported to be related to systemic inflammatory responses, characterized by elevated levels of cytokines IL- 6 and TNF- $\alpha[180,181]$. Proinflammatory cytokine, such as the mentioned H. pylori-related TNF- $\alpha$ and IL-6, have been revealed to regulate the expression of the mentioned RAAS components, especially angiotensinogen production in the liver and kidneys, further promoting systemic and local angiotensin II formation and angiotensin II-dependent hypertension [182]. It appears that under systemic inflammation induced by NAFLD, local inflammatory infiltration in the vasculature, kidney, and adipose tissue might accelerate the development and progression of arterial hypertension, and thus further research is needed.

Hypertension 2. H. pylori and MetS-related NAFLD may promote arterial hypertension by inducing augmented oxidative stress.

NAFLD has been suggested to be highly associated with oxidative stress [183]. In this respect, reactive oxygen species may play a role in $H$. pylori-related MetS extragastric systemic disorders, including atherosclerosis involved in arterial hypertension [184].

Hypertension 3. H. pylori and MetS-related NAFLD may promote arterial hypertension by inducing IR.

Accumulating experimental and clinical data have highlighted a close and causal relationship between NAFLD and H. pylori-related IR, a key component of MetS [53,185,186]. 
Mechanistically, in the setting of IR, excess free fatty acids released by adipose tissue stimulate ectopic fat deposits, including perivascular fat and renal sinus fat, thereby increasing the risk of arterial hypertension [187].

Hypertension 4. H. pylori and MetS-related NAFLD gastrointestinal dysbiosis may promote arterial hypertension.

H. pylori-related gastrointestinal dysbiosis has been associated with MetS-related systemic disorders, including arterial hypertension and NAFLD [45]. Currently, it is well recognized that NAFLD and gastrointestinal dysbiosis have been connected, and dysbiosis has been associated with the development and possibly the progression of NAFLD [188]. Strikingly, in the sequencing analysis of fecal microbiota, NAFLD patients have exhibited decreased richness and diversity of gut microbiota, especially increased Bacteroides and decreased Prevotella, which are closely connected with the production of short-chain fatty acids [189]; these changes could further contribute to arterial hypertension. In parallel with gastrointestinal dysbiosis, the investigation of fecal microbiome characteristics in NAFLD patients implied that NAFLD was linked with enriched genes encoding proteins essential in the biosynthesis of lipopolysaccharide, which can disrupt the intestinal barrier [189]. Subsequently, increased translocation of bacteria, including H. pylori [190], microbial-associated molecular patterns and gastrointestinal metabolites, elicit intestinal and hepatic inflammatory responses, thereby accelerating the progression of NAFLD. Moreover, systemic lipopolysaccharide levels are significantly raised in patients with NASH [191] and may stimulate systemic inflammation and induce arterial hypertension.

Hypertension 5. H. pylori and MetS-related NAFLD may promote arterial hypertension by increasing vasoconstriction and decreasing vasodilation.

The liver is the central site of the elimination of asymmetrical dimethylarginine (ADMA), which is an endogenous inhibitor of the mentioned NOS. There is evidence that ADMA is connected with endothelial dysfunction and vascular flow alterations in patients with arterial hypertension. Notably, circulating ADMA is positively related with the prevalence of MetS [192]. Moreover, clinical studies have revealed that NAFLD patients exhibit augmented levels of circulating ADMA, even independent of traditional cardiovascular risk factors [193]. Furthermore, NAFLD patients exhibit impaired eNOS (endothelial NOS) function in systemic circulating platelets [194], which may further lead to reduced nitric oxide production and impair nitric oxide-dependent vasodilatation. Additionally, RAAS activation by systemic inflammation and augmented production and secretion of RAAS components, including angiotensin II, can also increase vasoconstriction. Prospective studies also suggest that NAFLD is an independent pathogenic factor in the development and progression of arterial stiffness, which can, in turn, modulate vessel contractile function [195]. Therefore, it is possible that NAFLD can directly increase vasoconstriction and drive the development of arterial hypertension, and thus further investigation is needed.

Hypertension 6. H. pylori-related MetS-NAFLD genetic and epigenetic modifications may promote arterial hypertension.

Generated gene-metabolite-disease interaction networks show that NAFLD and arterial hypertension are interlinked by molecular signatures. Although a large amount of evidence exists for the relationship between NAFLD and arterial hypertension, there is little evidence on the genetic association between NAFLD and arterial hypertension. Bioinformatic analysis revealed that the AGTR1 (angiotensin receptor type 1) gene, also connected with H. pylori infection and MetS [196,197], might be involved in several signaling pathways connected with the development of NAFLD [198]. In a recent prospective cohort study, the gain-of-function A1166C (rs5186) variant in the AGTR1 gene represented a strong predictor of incident NAFLD and related arterial hypertension [199]. Thus, despite the previous unsuccessful clinical trial of angiotensin receptor blockers in managing fibrosis in NAFLD patients [200], patients with the AGTR1 A1166C variant may exhibit 
a subtype of NAFLD that may benefit more from the personalized usage of angiotensin receptor blockers.

Table 3. Promotion of arterial hypertension by proposed pathogenetic mechanisms of H. pylori and MetS-related NAFLD.

\begin{tabular}{|c|}
\hline Mechanisms \\
\hline $\begin{array}{l}\text { Promotion of arterial hypertension by: } \\
\bullet \quad \text { Augmented oxidative stress } \\
\text { - Increased insulin resistance } \\
\text { - Gastrointestinal dysbiosis } \\
\text { - Increased vasoconstriction and decreased vasodilation } \\
\bullet \quad \text { Genetic and epigenetic modifications }\end{array}$ \\
\hline
\end{tabular}

\section{Concluding Remarks}

H. pylori infection displays a pleiotropic effect beyond the alimentary tract and mounting evidence associates the infection with MetS, including arterial hypertension. The above-described mechanistic proposals have presented a pathogenetic substrate, showing how H. pylori infection may possibly exert its action and influence MetS-related arterial hypertension. Further research is warranted, however, to elucidate in depth the potential impact of Helicobacter pylori-related MetS on arterial hypertension, a serious public health problem with high global incidence and prevalence that continues to increase and may contribute to globally high levels of morbidity and mortality [1].

Identifying $H$. pylori and MetS-related NAFLD as an important risk factor for hypertension may be helpful for improving the risk prediction, identifying primary preventive strategies, and selecting a therapeutic program for arterial hypertension and associated systemic MetS-related pathologies, including cardiovascular disorders.

Funding: No grant or other financial support was received for this article.

Conflicts of Interest: Doulberis has received travel grants by Gilead Sciences Switzerland Sàrl. The other authors declare no conflict of interest.

\section{References}

1. Gupta, R.; Alcantara, R.; Popli, T.; Tariq, U.; Sood, A.; Mahajan, S.; Ayele, H.; Rajeswaran, Y.; Vyas, A.V. Firibastat: A Novel Brain Aminopeptidase Inhibitor-A New Era of Antihypertensive therapy. Curr. Probl. Cardiol. 2021, 100859. [CrossRef]

2. Guirguis-Blake, J.M.; Evans, C.V.; Webber, E.M.; Coppola, E.L.; Perdue, L.A.; Weyrich, M.S. Screening for Hypertension in Adults. JAMA 2021, 325, 1657-1669. [CrossRef]

3. Arguedas, J.A.; Leiva, V.; Wright, J.M. Blood pressure targets in adults with hypertension. Cochrane Database Syst. Rev. 2020, 2020, CD004349. [CrossRef]

4. Zhou, B.; Bentham, J.; Di Cesare, M.; Bixby, H.; Danaei, G.; Cowan, M.J.; Paciorek, C.J.; Singh, G.; Hajifathalian, K.; Bennett, J.E.; et al. Worldwide trends in blood pressure from 1975 to 2015: A pooled analysis of 1479 population-based measurement studies with 19.1 million participants. Lancet 2016, 389, 37-55. [CrossRef]

5. Kearney, P.M.; Whelton, M.; Reynolds, K.; Muntner, P.; Whelton, P.K.; He, J. Global burden of hypertension: Analysis of worldwide data. Lancet 2005, 365, 217-223. [CrossRef]

6. Stanaway, J.D.; Afshin, A.; Gakidou, E.; Lim, S.S.; Abate, D.; Abate, K.H.; Abbafati, C.; Abbasi, N.; Abbastabar, H.; Abd-Allah, F.; et al. Global, regional, and national comparative risk assessment of 84 behavioural, environmental and occupational, and metabolic risks or clusters of risks for 195 countries and territories, 1990-2017: A systematic analysis for the Global Burden of Disease Study 2017. Lancet 2018, 392, 1923-1994. [CrossRef]

7. Global Burden of Metabolic Risk Factors for Chronic Diseases Collaboration. Cardiovascular disease, chronic kidney disease, and diabetes mortality burden of cardiometabolic risk factors from 1980 to 2010: A comparative risk assessment. Lancet Diabetes Endocrinol. 2014, 2, 634-647. [CrossRef]

8. Oparil, S.; Acelajado, M.C.; Bakris, G.L.; Berlowitz, D.R.; Cifkova, R.; Dominiczak, A.F.; Grassi, G.; Jordan, J.; Poulter, N.R.; Rodgers, A.; et al. Hypertension. Nat. Rev. Dis. Primers 2018, 4, 18014. [CrossRef]

9. Su, C.; Xue, J.; Ye, C.; Chen, A. Role of the central renin-angiotensin system in hypertension (Review). Int. J. Mol. Med. 2021, 47, 95. [CrossRef] 
10. Vecchiola, A.; Fuentes, C.A.; Solar, I.; Lagos, C.F.; Opazo, M.C.; Muñoz-Durango, N.; Riedel, C.; Owen, G.I.; Kalergis, A.M.; Fardella, C.E. Eplerenone Implantation Improved Adipose Dysfunction Averting RAAS Activation and Cell Division. Front. Endocrinol. 2020, 11, 223. [CrossRef]

11. Zhou, M.-S.; Schulman, I.; Zeng, Q. Link between the renin-angiotensin system and insulin resistance: Implications for cardiovascular disease. Vasc. Med. 2012, 17, 330-341. [CrossRef]

12. Xie, M.; Yuan, S.; Zeng, Y.; Zheng, C.; Yang, Y.; Dong, Y.; He, Q. ATP2B1 gene polymorphisms rs2681472 and rs17249754 are associated with susceptibility to hypertension and blood pressure levels. Medicine 2021, 100, e25530. [CrossRef] [PubMed]

13. He, F.J.; Li, J.; MacGregor, G.A. Effect of longer term modest salt reduction on blood pressure: Cochrane systematic review and meta-analysis of randomised trials. BMJ 2013, 346, f1325. [CrossRef]

14. Aburto, N.J.; Hanson, S.; Gutierrez, H.; Hooper, L.; Elliott, P.; Cappuccio, F.P. Effect of increased potassium intake on cardiovascular risk factors and disease: Systematic review and meta-analyses. BMJ 2013, 346, f1378. [CrossRef]

15. Canale, M.; Noce, A.; Di Lauro, M.; Marrone, G.; Cantelmo, M.; Cardillo, C.; Federici, M.; Di Daniele, N.; Tesauro, M. Gut Dysbiosis and Western Diet in the Pathogenesis of Essential Arterial Hypertension: A Narrative Review. Nutrients 2021, $13,1162$. [CrossRef]

16. Sacks, F.M.; Campos, H. Dietary Therapy in Hypertension. N. Eng. J. Med. 2010, 362, 2102-2112. [CrossRef] [PubMed]

17. Landsberg, L. Insulin-mediated sympathetic stimulation: Role in the pathogenesis of obesity-related hypertension (or, how insulin affects blood pressure, and why). J. Hypertens. 2001, 19, 523-528. [CrossRef]

18. Virdis, A.; Giannarelli, C.; Fritsch Neves, M.; Taddei, S.; Ghiadoni, L. Cigarette Smoking and Hypertension. Curr. Pharm. Des. 2010, 16, 2518-2525. [CrossRef] [PubMed]

19. Penna, C.; Femminò, S.; Alloatti, G.; Brizzi, M.; Angelone, T.; Pagliaro, P. Extracellular Vesicles in Comorbidities Associated with Ischaemic Heart Disease: Focus on Sex, an Overlooked Factor. J. Clin. Med. 2021, 10, 327. [CrossRef]

20. Rizzoni, D.; Porteri, E.; Castellano, M.; Bettoni, G.; Muiesan, M.L.; Tiberio, G.; Giulini, S.M.; Rossi, G.; Bernini, G.; Agabiti-Rosei, E. Endothelial Dysfunction in Hypertension Is Independent From the Etiology and From Vascular Structure. Hypertension 1998, 31, 335-341. [CrossRef]

21. De Filippis, A.; Ullah, H.; Baldi, A.; DaCrema, M.; Esposito, C.; Garzarella, E.U.; Santarcangelo, C.; Tantipongpiradet, A.; Daglia, M. Gastrointestinal Disorders and Metabolic Syndrome: Dysbiosis as a Key Link and Common Bioactive Dietary Components Useful for their Treatment. Int. J. Mol. Sci. 2020, 21, 4929. [CrossRef] [PubMed]

22. Guo, Y.; Li, X.; Wang, Z.; Yu, B. Gut Microbiota Dysbiosis in Human Hypertension: A Systematic Review of Observational Studies. Front. Cardiovasc. Med. 2021, 8, 414. [CrossRef]

23. Boziki, M.; Grigoriadis, N.; Papaefthymiou, A.; Doulberis, M.; Polyzos, S.A.; Gavalas, E.; Deretzi, G.; Karafoulidou, E.; Kesidou, E.; Taloumtzis, C.; et al. The trimebutine effect on Helicobacter pylori-related gastrointestinal tract and brain disorders: A hypothesis. Neurochem. Int. 2021, 144, 104938. [CrossRef] [PubMed]

24. McMaster, W.G.; Kirabo, A.; Madhur, M.S.; Harrison, D.G. Inflammation, Immunity, and Hypertensive End-Organ Damage. Circ. Res. 2015, 116, 1022-1033. [CrossRef]

25. Weinstein, S.; Leibowitz, A. Role of the immune system in the pathogenesis of hypertension. Harefuah 2021, 160, $256-259$.

26. Wenzel, U.O.; Ehmke, H.; Bode, M. Immune mechanisms in arterial hypertension. Recent Adv. 2021, 385, 393-404. [CrossRef] [PubMed]

27. Bellicha, A.; van Baak, M.A.; Battista, F.; Beaulieu, K.; Blundell, J.E.; Busetto, L.; Carraca, E.V.; Dicker, D.; Encantado, J.; Ermolao, A.; et al. Effect of exercise training before and after bariatric surgery: A systematic review and meta-analysis. Obes. Rev. 2021, 22, e13296. [CrossRef] [PubMed]

28. Ungvari, Z.; Toth, P.; Tarantini, S.; Prodan, C.I.; Sorond, F.; Merkely, B.; Csiszar, A. Hypertension-induced cognitive impairment: From pathophysiology to public health. Nat. Rev. Nephrol. 2021, 17, 639-654. [CrossRef]

29. Jennings, J.R.; Muldoon, M.F.; Ryan, C.; Price, J.C.; Greer, P.; Sutton-Tyrrell, K.; van der Veen, F.M.; Meltzer, C.C. Reduced cerebral blood flow response and compensation among patients with untreated hypertension. Neurology 2005, 64, 1358-1365. [CrossRef]

30. Muller, M.; van der Graaf, Y.; Visseren, F.L.; Mali, W.P.T.M.; Geerlings, M.I. Hypertension and longitudinal changes in cerebral blood flow: The SMART-MR study. Ann. Neurol. 2012, 71, 825-833. [CrossRef]

31. Immink, R.V.; van den Born, B.-J.H.; van Montfrans, G.A.; Koopmans, R.P.; Karemaker, J.M.; van Lieshout, J.J. Impaired Cerebral Autoregulation in Patients with Malignant Hypertension. Circulation 2004, 110, 2241-2245. [CrossRef]

32. Mohammed, T.; Singh, M.; Tiu, J.G.; Kim, A.S. Etiology and management of hypertension in patients with cancer. Cardio-Oncology 2021, 7, 14. [CrossRef]

33. Stocks, T.; Van Hemelrijck, M.; Manjer, J.; Bjørge, T.; Ulmer, H.; Hallmans, G.; Lindkvist, B.; Selmer, R.; Nagel, G.; Tretli, S.; et al. Blood Pressure and Risk of Cancer Incidence and Mortality in the Metabolic Syndrome and Cancer Project. Hypertension 2012, 59, 802-810. [CrossRef] [PubMed]

34. Hooi, J.K.; Lai, W.Y.; Ng, W.K.; Suen, M.M.; Underwood, F.E.; Tanyingoh, D.; Malfertheiner, P.; Graham, D.Y.; Wong, V.W.; Wu, J.C.; et al. Global Prevalence of Helicobacter pylori Infection: Systematic Review and Meta-Analysis. Gastroenterology 2017, 153, 420-429. [CrossRef]

35. Haile, K.; Timerga, A. Evaluation of Hematological Parameters of Helicobacter pylori-Infected Adult Patients at Southern Ethiopia: A Comparative Cross-Sectional Study. J. Blood Med. 2021, 12, 77-84. [CrossRef] [PubMed] 
36. Polyzos, S.A.; Kountouras, J.; Mantzoros, C.S. Helicobacter pylori infection and nonalcoholic fatty liver disease: Are the four meta-analyses favoring an intriguing association pointing to the right direction? Metabolism 2019, 96, 3-5. [CrossRef]

37. Doulberis, M.; Papaefthymiou, A.; Polyzos, S.A.; Bargiotas, P.; Liatsos, C.; Srivastava, D.S.; Zavos, C.; Katsinelos, P.; Kountouras, J. Association between Active Helicobacter pylori Infection and Glaucoma: A Systematic Review and Meta-Analysis. Microorganisms 2020, 8, 894. [CrossRef] [PubMed]

38. Franceschi, F.; Gasbarrini, A.; Polyzos, S.A.; Kountouras, J. Extragastric Diseases and Helicobacter pylori. Helicobacter 2015, 20, 40-46. [CrossRef]

39. Kountouras, J.; Polyzos, S.A.; Katsinelos, P.; Zeglinas, C.; Artemaki, F.; Tzivras, D.; Vardaka, E.; Gavalas, E.; Romiopoulos, I.; Simeonidou, C.; et al. Cardio-cerebrovascular disease and Helicobacter pylori-Related metabolic syndrome: We consider eradication therapy as a potential cardio-cerebrovascular prevention strategy. Int. J. Cardiol. 2016, 229, 17-18. [CrossRef]

40. Kountouras, J.; Doulberis, M.; Polyzos, S.A.; Katsinelos, T.; Vardaka, E.; Kountouras, C.; Arapoglou, S.; Exadaktylos, A.K.; Deretzi, G.; Tsolaki, M.; et al. Impact of Helicobacter pylori and/or Helicobacter pylor-Related metabolic syndrome on incidence of all-cause and Alzheimer's dementia. Alzheimer's Dement. 2019, 15, 723-725. [CrossRef]

41. Pellicano, R.; Ianiro, G.; Fagoonee, S.; Settanni, C.R.; Gasbarrini, A. Review: Extragastric diseases and Helicobacter pylori. Helicobacter 2020, 25, e12741. [CrossRef]

42. Doheim, M.F.; Altaweel, A.A.; Elgendy, M.G.; Elshanbary, A.; Dibas, M.; Ali, A.A.H.A.; Dahy, T.M.; Sharaf, A.K.; Hassan, A.E. Association between Helicobacter pylori infection and stroke: A meta-analysis of 273,135 patients. J. Neurol. 2020, 268, 3238-3248. [CrossRef]

43. Doulberis, M.; Kotronis, G.; Gialamprinou, D.; Polyzos, S.A.; Papaefthymiou, A.; Katsinelos, P.; Kountouras, J. Alzheimer's disease and gastrointestinal microbiota; impact of Helicobacter pylori infection involvement. Int. J. Neurosci. 2020, 131, $289-301$. [CrossRef]

44. Kountouras, J.; Kapetanakis, N.; Zavos, C.; Polyzos, S.A.; Vardaka, E.; Katsinelos, P.; Romiopulos, I.; Anastasiadou, K.; Giorgakis, N.; Nikolaidou, C.; et al. Helicobacter pylori and Colorectal Cancer Risk—Letter. Cancer Epidemiol. Biomark. Prev. 2014, $23,365$. [CrossRef] [PubMed]

45. Kountouras, J.; Boziki, M.; Polyzos, S.; Katsinelos, P.; Gavalas, E.; Zeglinas, C.; Tzivras, D.; Romiopoulos, I.; Giorgakis, N.; Anastasiadou, K.; et al. The Emerging Role of Helicobacter pylori-Induced Metabolic Gastrointestinal Dysmotility and Neurodegeneration. Curr. Mol. Med. 2018, 17, 389-404. [CrossRef]

46. Kountouras, J.; Polyzos, S.A.; Doulberis, M.; Zeglinas, C.; Artemaki, F.; Vardaka, E.; Deretzi, G.; Giartza-Taxidou, E.; Tzivras, D.; Vlachaki, E.; et al. Potential impact of Helicobacter pylori-Related metabolic syndrome on upper and lower gastrointestinal tract oncogenesis. Metabolism 2018, 87, 18-24. [CrossRef]

47. Doulberis, M.; Kotronis, G.; Thomann, R.; Polyzos, S.S.A.; Boziki, M.; Gialambrinou, D.; Deretzi, G.; Katsinelos, P.; Kountouras, J. Impact of Helicobacter pylori on Alzheimer's disease: What do we know so far? Helicobacter 2017, 23, e12454. [CrossRef]

48. Polyzos, S.A.; Zeglinas, C.; Artemaki, F.; Doulberis, M.; Kazakos, E.; Katsinelos, P.; Kountouras, J. Helicobacter pylori infection and esophageal adenocarcinoma: A review and a personal view. Ann. Gastroenterol. 2017, 31, 8-13. [CrossRef] [PubMed]

49. Katsinelos, T.; Doulberis, M.; Polyzos, S.A.; Papaefthymiou, A.; Katsinelos, P.; Kountouras, J. Molecular Links Between Alzheimer's Disease and Gastrointestinal Microbiota: Emphasis on Helicobacter pylori Infection Involvement. Curr. Mol. Med. 2019, 20, 3-12. [CrossRef] [PubMed]

50. Polyzos, S.A.; Kountouras, J. Helicobacter pylori Infection: One More Contributor to Nonalcoholic Fatty Liver Disease Pathophysiology. J. Clin. Gastroenterol. 2019, 53, 624-626. [CrossRef] [PubMed]

51. Franceschi, F.; Annalisa, T.; Teresa, D.R.; Giovanna, D.A.; Laniro, G.; Franco, S.; Viviana, G.; Valentina, T.; Riccard, L.L.; Gasbarinni, A. Role of Helicobacter pylori infection on nutrition and metabolism. World J. Gastroenterol. 2014, 20, 12809-12817. [CrossRef] [PubMed]

52. Kountouras, J.; Doulberis, M.; Papaefthymiou, A.; Polyzos, S.A. Impact of Helicobacter pylori-Linked metabolic syndrome on non-alcoholic fatty liver disease and its connected atrial fibrillation risk. Liver Int. 2020, 40, 2036-2037. [CrossRef] [PubMed]

53. Doulberis, M.; Srivastava, S.; Polyzos, S.A.; Kountouras, J.; Papaefthymiou, A.; Klukowska-Rötzler, J.; Blank, A.; Exadaktylos, A.K.; Srivastava, D.S. Active Helicobacter pylori Infection is Independently Associated with Nonalcoholic Steatohepatitis in Morbidly Obese Patients. J. Clin. Med. 2020, 9, 933. [CrossRef]

54. Boziki, M.; Polyzos, S.A.; Papaefthymiou, A.; Doulberis, M.; Bakirtzis, C.; Sintila, S.-.A.; Touloumtzi, M.; Grigoriadis, N.; Kountouras, J. Potential impact of Helicobacter pylori-Related metabolic syndrome and Galectin-3 on liver, chronic kidney and brain disorders. Metabolism 2021, 118, 154736. [CrossRef] [PubMed]

55. Kountouras, J.; Papaefthymiou, A.; Doulberis, M.; Polyzos, S.A.; Zavos, C.; Kazakos, E.; Tzika, S.K.; Vardaka, E.; Liatsos, C.; Katsinelos, P. Impact of Helicobacter pylori-Related Metabolic Syndrome and Gastroesophageal Reflux Disease on the Risk of Acute Myocardial Infarction. J. Neurogastroenterol. Motil. 2021, 27, 147-148. [CrossRef] [PubMed]

56. Tournier, J.-N. Pandemic Legion History More Complex than Previously Thought. mBio 2020, 11, e02377-20. [CrossRef]

57. Ealey, K.N.; Phillips, J.; Sung, H.-K. COVID-19 and obesity: Fighting two pandemics with intermittent fasting. Trends Endocrinol. Metab. 2021, 32, 706-720. [CrossRef]

58. Vallianou, N.G.; Geladari, E.; Kounatidis, D. Microbiome and hypertension. J. Cardiovasc. Med. 2020, 21, 83-88. [CrossRef]

59. Madhur, M.S.; Elijovich, F.; Alexander, M.R.; Pitzer, A.; Ishimwe, J.; Van Beusecum, J.P.; Patrick, D.M.; Smart, C.D.; Kleyman, T.R.; Kingery, J.; et al. Hypertension. Circ. Res. 2021, 128, 908-933. [CrossRef] 
60. Tang, B.W.; Wang, X.M.; Wu, J. Progress in research on the relationship between Helicobacter pylori infection and cardiovascular diseases and its risk factors. Zhonghua Yu Fang Yi Xue Za Zhi 2020, 54, 327-331.

61. Jukic, A.; Bozic, D.; Kardum, D.; Becic, T.; Luksic, B.; Vrsalovic, M.; Ljubkovic, M.; Fabijanic, D. Helicobacter pylori infection and severity of coronary atherosclerosis in patients with chronic coronary artery disease. Ther. Clin. Risk Manag. 2017, 13, 933-938. [CrossRef] [PubMed]

62. Wan, Z.; Hu, L.; Hu, M.; Lei, X.; Huang, Y.; Lv, Y. Helicobacter pylori infection and prevalence of high blood pressure among Chinese adults. J. Hum. Hypertens. 2017, 32, 158-164. [CrossRef]

63. Nasrat, S.A.M.; Nasrat, A.M. An Alternative Approach for the Rising Challenge of Hypertensive Illness via Helicobacter pylori Eradication. Cardiol. Res. 2015, 6, 221-225. [CrossRef]

64. Migneco, A.; Ojetti, V.; Specchia, L.; Franceschi, F.; Candelli, M.; Mettimano, M.; Montebelli, R.; Savi, L.; Gasbarrini, G. Eradication of Helicobacter pylori infection improves blood pressure values in patients affected by hypertension. Helicobacter 2003, 8, 585-589. [CrossRef] [PubMed]

65. Newberry, S.J.; Chung, M.; Anderson, C.A.; Chen, C.; Fu, Z.; Tang, A.; Zhao, N.; Booth, M.; Marks, J.; Hollands, S.; et al. Effects of Dietary Sodium and Potassium Intake on Chronic Disease Outcomes and Related Risk Factors. Syst. Rev. 2018. [CrossRef]

66. Intersalt Cooperative Research Group. Intersalt: An international study of electrolyte excretion and blood pressure. Results for 24 hour urinary sodium and potassium excretion. BMJ 1988, 297, 319-328. [CrossRef]

67. The EUROGAST Study Group. An international association between Helicobacter pylori infection and gastric cancer. Lancet 1993, 341, 1359-1362. [CrossRef]

68. Fox, J.G.; Dangler, C.A.; Taylor, N.S.; King, A.; Koh, T.J.; Wang, T.C. High-salt diet induces gastric epithelial hyperplasia and parietal cell loss, and enhances Helicobacter pylori colonization in C57BL/6 mice. Cancer Res. 1999, 59, 4823-4828. [PubMed]

69. Kato, S.; Tsukamoto, T.; Mizoshita, T.; Tanaka, H.; Kumagai, T.; Ota, H.; Katsuyama, T.; Asaka, M.; Tatematsu, M. High salt diets dose-dependently promote gastric chemical carcinogenesis in Helicobacter pylori-Infected Mongolian gerbils associated with a shift in mucin production from glandular to surface mucous cells. Int. J. Cancer 2006, 119, 1558-1566. [CrossRef] [PubMed]

70. Dahl, L.K. Possible role of salt intake in the development of essential hypertension*. Int. J. Epidemiol. 2005, 34, 967-972. [CrossRef]

71. Lee, Y.Y.; Ismail, A.W.; Mustaffa, N.; Musa, K.I.; Majid, N.A.; Choo, K.E.; Raj, S.M.; Derakhshan, M.H.; Malaty, H.M.; Graham, D.Y. Sociocultural and Dietary Practices Among Malay Subjects in the North-Eastern Region of Peninsular Malaysia: A Region of Low Prevalence of Helicobacter pylori Infection. Helicobacter 2012, 17, 54-61. [CrossRef]

72. Asaka, M.; Kimura, T.; Kudo, M.; Takeda, H.; Mitani, S.; Miyazaki, T.; Miki, K.; Graham, D.Y. Relationship of Helicobacter pylori to serum pepsinogens in an asymptomatic Japanese population. Gastroenterology 1992, 102, 760-766. [CrossRef]

73. Luft, F.C.; Weinberger, M.H. Heterogeneous responses to changes in dietary salt intake: The salt-sensitivity paradigm. Am. J. Clin. Nutr. 1997, 65, 612S-617S. [CrossRef]

74. Fujita, T.; Henry, W.L.; Bartter, F.C.; Lake, C.; Delea, C.S. Factors influencing blood pressure in salt-sensitive patients with hypertension. Am. J. Med. 1980, 69, 334-344. [CrossRef]

75. Kawasaki, T.; Delea, C.S.; Bartter, F.C.; Smith, H. The effect of high-sodium and low-sodium intakes on blood pressure and other related variables in human subjects with idiopathic hypertension. Am. J. Med. 1978, 64, 193-198. [CrossRef]

76. Feng, W.; Dell'Italia, L.J.; Sanders, P.W. Novel Paradigms of Salt and Hypertension. J. Am. Soc. Nephrol. 2017, $28,1362-1369$. [CrossRef] [PubMed]

77. Guyton, A.C. Kidneys and fluids in pressure regulation. Small volume but large pressure changes. Hypertension 1992, 19 , I2. [CrossRef]

78. Bragulat, E.; de la Sierra, A. Salt Intake, Endothelial Dysfunction, and Salt-Sensitive Hypertension. J. Clin. Hypertens. 2002, 4, 41-46. [CrossRef]

79. Kawarazaki, W.; Mizuno, R.; Nishimoto, M.; Ayuzawa, N.; Hirohama, D.; Ueda, K.; Kawakami-Mori, F.; Oba, S.; Marumo, T.; Fujita, T. Salt causes aging-associated hypertension via vascular Wnt5a under Klotho deficiency. J. Clin. Investig. 2020, 130, 4152-4166. [CrossRef] [PubMed]

80. Kawarazaki, W.; Nagase, M.; Yoshida, S.; Takeuchi, M.; Ishizawa, K.; Ayuzawa, N.; Ueda, K.; Fujita, T. Angiotensin II- and Salt-Induced Kidney Injury through Rac1-Mediated Mineralocorticoid Receptor Activation. J. Am. Soc. Nephrol. 2012, 23, 997-1007. [CrossRef]

81. Edwards, A.; McDonough, A.A. Impact of angiotensin II-mediated stimulation of sodium transporters in the nephron assessed by computational modeling. Am. J. Physiol.-Ren. Physiol. 2019, 317, F1656-F1668. [CrossRef] [PubMed]

82. Winternitz, S.R.; Katholi, R.E.; Oparil, S. Role of the Renal Sympathetic Nerves in the Development and Maintenance of Hypertension in the Spontaneously Hypertensive Rat. J. Clin. Investig. 1980, 66, 971-978. [CrossRef]

83. Hall, J.E.; do Carmo, J.M.; da Silva, A.A.; Wang, Z.; Hall, M.E. Obesity-Induced Hypertension. Circ. Res. 2015, 116, 991-1006. [CrossRef]

84. Polichnowski, A.J.; Griffin, K.A.; Long, J.; Williamson, G.A.; Bidani, A.K. Blood pressure-renal blood flow relationships in conscious angiotensin II- and phenylephrine-infused rats. Am. J. Physiol. Physiol. 2013, 305, F1074-F1084. [CrossRef] [PubMed]

85. Shibata, S.; Nagase, M.; Yoshida, S.; Kawachi, H.; Fujita, T. Podocyte as the Target for Aldosterone. Hypertension 2007, 49, 355-364. [CrossRef] [PubMed] 
86. Nagase, M.; Yoshida, S.; Shibata, S.; Nagase, T.; Gotoda, T.; Ando, K.; Fujita, T. Enhanced Aldosterone Signaling in the Early Nephropathy of Rats with Metabolic Syndrome: Possible Contribution of Fat-Derived Factors. J. Am. Soc. Nephrol. 2006, 17, 3438-3446. [CrossRef]

87. Xu, T.; Zhu, G.; Han, S. Prevalence of and lifestyle factors associated with metabolic syndrome determined using multi-level models in Chinese adults from a cross-sectional survey. Medicine 2020, 99, e22883. [CrossRef]

88. Shen, X.; Jin, C.; Wu, Y.; Zhang, Y.; Wang, X.; Huang, W.; Li, J.; Wu, S.; Gao, X. Prospective study of perceived dietary salt intake and the risk of non-alcoholic fatty liver disease. J. Hum. Nutr. Diet. 2019, 32, 802-809. [CrossRef] [PubMed]

89. Jonsdottir, S.E.; Brader, L.; Gunnarsdóttir, I.; Magnusdottir, O.K.; Schwab, U.; Kolehmainen, M.; Risérus, U.; Herzig, K.-H.; Cloetens, L.; Helgegren, H.; et al. Adherence to the Nordic Nutrition Recommendations in a Nordic population with metabolic syndrome: High salt consumption and low dietary fibre intake (The SYSDIET study). Food Nutr. Res. 2013, 57, 21391. [CrossRef]

90. Patel, P.N.; Shah, R.Y.; Ferguson, J.F.; Reilly, M.P. Human Experimental Endotoxemia in Modeling the Pathophysiology, Genomics, and Therapeutics of Innate Immunity in Complex Cardiometabolic Diseases. Arter. Thromb. Vasc. Biol. 2015, 35, 525-534. [CrossRef]

91. Aladhami, A.K.; Unger, C.A.; Ennis, S.L.; Altomare, D.; Ji, H.; Hope, M.C.; Velázquez, K.T.; Enos, R.T. Macrophage tumor necrosis factor-alpha deletion does not protect against obesity-associated metabolic dysfunction. FASEB J. 2021, 35, e21665. [CrossRef] [PubMed]

92. Coskun, S.; Kasirga, E.; Yilmaz, O.; Bayindir, P.; Akil, I.; Yuskel, H.; Polat, M.; Ssnlidag, T. Is Helicobacter pylori related to endothelial dysfunction during childhood? Pediatr. Int. 2008, 50, 150-153. [CrossRef]

93. Maciorkowska, E. Soluble adhesion molecules ICAM-1, VCAM-1, P-selectin in children with Helicobacter pylori infection. World J. Gastroenterol. 2005, 11, 6745. [CrossRef]

94. Consolazio, A.; Borgia, M.C.; Ferro, D.; Iacopini, F.; Paoluzi, O.A.; Crispino, P.; Nardi, F.; Rivera, M.; Paoluzi, P. Increased thrombin generation and circulating levels of tumour necrosis factor- $\alpha$ in patients with chronic Helicobacter pylor-Positive gastritis. Aliment. Pharmacol. Ther. 2004, 20, 289-294. [CrossRef] [PubMed]

95. Russo, F.; Jirillo, E.; Clemente, C.; Messa, C.; Chiloiro, M.; Riezzo, G.; Amati, L.; Caradonna, L.; Di Leo, D. Circulating cytokines and gastrin levels in asymptomatic subjects infected by Helicobacter pylori (H. pylori). Immunopharmacol. Immunotoxicol. 2001, 23 , 13-24. [CrossRef]

96. Kountouras, J.; Papaefthymiou, A.; Doulberis, M.; Polyzos, S.A. Influence of Helicobacter pylori-Connected metabolic syndrome on non-alcoholic fatty liver disease and its related colorectal neoplasm high risk. Liver Int. 2019, 40, 475-476. [CrossRef]

97. Boziki, M.; Grigoriadis, N.; Doulberis, M.; Papaefthymiou, A.; Polyzos, S.A.; Kountouras, J. Potential impact of Helicobacter pylori-Related Galectin-3 on chronic kidney, cardiovascular and brain disorders in decompensated cirrhosis. Dig. Liver Dis. 2019, 52, 121-123. [CrossRef]

98. Queiroz, T.; Lakkappa, N.; Lazartigues, E. ADAM17-Mediated Shedding of Inflammatory Cytokines in Hypertension. Front. Pharmacol. 2020, 11, 1154. [CrossRef] [PubMed]

99. Martínez-Casales, M.; Hernanz, R.; Alonso, M.J. Vascular and Macrophage Heme Oxygenase-1 in Hypertension: A Mini-Review. Front. Physiol. 2021, 12, 643435. [CrossRef]

100. Jafarzadeh, A.; Hassanshahi, G.H.; Nemati, M. Serum Levels of High-Sensitivity C-Reactive Protein (hs-CRP) in Helicobacter pylori-Infected Peptic Ulcer Patients and Its Association with Bacterial CagA Virulence Factor. Dig. Dis. Sci. 2009, 54, $2612-2616$. [CrossRef]

101. Niccoli, G.; Franceschi, F.; Cosentino, N.; Giupponi, B.; De Marco, G.; Merra, G.; Conte, M.; Montone, R.A.; Ferrante, G.; Bacà, M.; et al. Coronary atherosclerotic burden in patients with infection by CagA-positive strains of Helicobacter pylori. Coron. Artery Dis. 2010, 21, 217-221. [CrossRef] [PubMed]

102. Kowalski, M. Helicobacter pylori (H. pylori) infection in coronary artery disease: Influence of H. pylori eradication on coronary artery lumen after percutaneous transluminal coronary angioplasty. The detection of $H$. pylori specific DNA in human coronary atherosclerot. J. Physiol. Pharmacol. 2001, 52, 3-31.

103. Franceschi, F.; Sepulveda, A.R.; Gasbarrini, A.; Polla, P.; Silveri, N.G.; Gasbarrini, G.; Graham, D.Y.; Gengta, R.M. Cross-Reactivity of Anti-CagA Antibodies With Vascular Wall Antigens. Circulation 2002, 106, 430-434. [CrossRef] [PubMed]

104. Diomedi, M.; Stanzione, P.; Sallustio, F.; Leone, G.; Renna, A.; Missagi, G.; Fontana, C.; Pasqualetti, P.; Pietroiusti, A. CytotoxinAssociated Gene-A-Positive Helicobacter pylori S trains Infection Increases the Risk of Recurrent Atherosclerotic Stroke. Helicobacter 2008, 13, 525-531. [CrossRef]

105. Nakagawa, H.; Tamura, T.; Mitsuda, Y.; Gotto, Y.; Kamiya, Y.; Kondo, T.; Wakai, K.; Hamajima, N. Significant Association between Serum Interleukin-6 and Helicobacter pylori Antibody Levels among H. pylori -Positive Japanese Adults. Mediat. Inflamm. 2013, 2013, 142358. [CrossRef]

106. Reddy, P.; Lent-Schochet, D.; Ramakrishnan, N.; McLaughlin, M.; Jialal, I. Metabolic syndrome is an inflammatory disorder: A conspiracy between adipose tissue and phagocytes. Clin. Chim. Acta 2019, 496, 35-44. [CrossRef]

107. Ramji, D.P.; Davies, T.S. Cytokines in atherosclerosis: Key players in all stages of disease and promising therapeutic targets. Cytokine Growth Factor Rev. 2015, 26, 673-685. [CrossRef]

108. Rechciński, T.; Kasprzak, J.D.; Chmiela, M.; Krzemińska-Pakuła, M.; Rudnicka, W. Patients with unstable angina pectoris present increased humoral response against Helicobacter pylori in comparison with patients with aggravated dyspepsia. Acta Microbiol. Pol. 2002, 51, 339-344. [PubMed] 
109. Strachan, D.P. Non-gastrointestinal consequences of Helicobacter pylori infection. Br. Med. Bull. 1998, 54, 87-93. [CrossRef]

110. Zhu, J.; Katz, R.J.; Quyyumi, A.A.; Canos, D.A.; Rott, D.; Csako, G.; Zalles-Ganley, A.; Ogunmakinwa, J.; Wasserman, A.G.; Epstein, S.E. Association of Serum Antibodies to Heat-Shock Protein 65 With Coronary Calcification Levels. Circulation 2004, 109, 36-41. [CrossRef] [PubMed]

111. Kountouras, J.; Gavalas, E.; Boziki, M.; Zavos, C. Helicobacter pylori may be involved in cognitive impairment and dementia development through induction of atrophic gastritis, vitamin B-12-folate deficiency, and hyperhomocysteinemia sequence. Am. J. Clin. Nutr. 2007, 86, 805-806. [CrossRef]

112. Vijayvergiya, R.; Vadivelu, R. Role of Helicobacter pylori infection in pathogenesis of atherosclerosis. World, J. Cardiol. 2015, 7, 134-143. [CrossRef]

113. Piazzolla, G.; Candigliota, M.; Fanelli, M.; Castrovilli, A.; Berardi, E.; Antonica, G.; Battaglia, S.; Solfrizzi, V.; Sabbà, C.; Tortorella, C. Hyperhomocysteinemia is an independent risk factor of atherosclerosis in patients with metabolic syndrome. Diabetol. Metab. Syndr. 2019, 11, 87-89. [CrossRef]

114. Wang, J.; Du, J.; Fan, R. Exploration of the risk factors of essential hypertension with hyperhomocysteinemia: A hospital-based study and nomogram analysis. Clinics 2021, 76, e2233. [CrossRef] [PubMed]

115. Cohen, E.; Levi, A.; Vecht-Lifshitz, S.E.; Goldberg, E.; Garty, M.; Krause, I. Assessment of a Possible Link Between Hyperhomocysteinemia and Hyperuricemia. J. Investig. Med. 2015, 63, 534-538. [CrossRef]

116. Bostom, A.G.; Shemin, D.; Lapane, K.L.; Sutherland, P.; Nadeau, M.R.; Wilson, P.W.; Yoburn, D.; Bausserman, L.; Tofler, G.; Jacques, P.F.; et al. Hyperhomocysteinemia, hyperfibrinogenemia, and lipoprotein (a) excess in maintenance dialysis patients: A matched case-control study. Atherosclerosis 1996, 125, 91-101. [CrossRef]

117. Longo-Mbenza, B.; Mokondjimobe, N.; Mokolndjimobe, E.; Gombet, T.; Assori, I.N.; Ibara, J.R.; Ellenga-Mbola, B.; Vangu, D.N.; Fuele, S.M. Helicobacter pylori infection is identified as a cardiovascular risk factor in Central Africans. Vasc. Health Risk Manag. 2012, 6, 455-461. [CrossRef]

118. Xiong, X.; Chen, J.; He, M.; Wu, T.; Yang, H. Helicobacter pylori infection and the prevalence of hypertension in Chinese adults: The Dongfeng-Tongji cohort. J. Clin. Hypertens. 2020, 22, 1389-1395. [CrossRef] [PubMed]

119. Rothwell, P.M.; Howard, S.C.; Power, D.A.; Gutnikov, S.A.; Algra, A.; van Gijn, J.; Clark, T.; Murphy, M.F.; Warlow, C.P. Fibrinogen Concentration and Risk of Ischemic Stroke and Acute Coronary Events in 5113 Patients With Transient Ischemic Attack and Minor Ischemic Stroke. Stroke 2004, 35, 2300-2305. [CrossRef]

120. Chuang, S.-Y.; Bai, C.-H.; Chen, W.-H.; Lien, L.-M.; Pan, W.-H. Fibrinogen Independently Predicts the Development of Ischemic Stroke in a Taiwanese Population. Stroke 2009, 40, 1578-1584. [CrossRef] [PubMed]

121. Guedes, A.F.; Moreira, C.; Nogueira, J.B.; Santos, N.C.; Carvalho, F.A. Fibrinogen-erythrocyte binding and hemorheology measurements in the assessment of essential arterial hypertension patients. Nanoscale 2019, 11, 2757-2766. [CrossRef]

122. Ferrannini, E.; Buzzigoli, G.; Bonadonna, R.; Giorico, M.A.; Oleggini, M.; Graziadei, L.; Pedrinelli, R.; Brandi, L.; Bevilacqua, S. Insulin Resistance in Essential Hypertension. N. Engl. J. Med. 1987, 317, 350-357. [CrossRef]

123. Mancusi, C.; Izzo, R.; di Gioia, G.; Losi, M.A.; Barbato, E.; Morisco, C. Insulin Resistance the Hinge Between Hypertension and Type 2 Diabetes. High Blood Press. Cardiovasc. Prev. 2020, 27, 515-526. [CrossRef] [PubMed]

124. Xu, J.; Kitada, M.; Ogura, Y.; Koya, D. Relationship Between Autophagy and Metabolic Syndrome Characteristics in the Pathogenesis of Atherosclerosis. Front. Cell Dev. Biol. 2021, 9, 641852. [CrossRef]

125. Martínez Torres, A.; Martínez Gaensly, M. Helicobacter pylori: ¿un nuevo factor de riesgo cardiovascular? Rev. Esp. Cardiol. 2002, 55, 652-656. [CrossRef]

126. Murray, L.J.; Bamford, K.B.; Kee, F.; McMaster, D.; Cambien, F.; Dallongeville, J.; Evans, A. Infection with virulent strains of Helicobacter pylori is not associated with ischaemic heart disease: Evidence from a population-based case-control study of myocardial infarction. Atherosclerosis 2000, 149, 379-385. [CrossRef]

127. Rogha, M.; Nikvarz, M.; Pourmoghaddas, Z.; Shirneshan, K.; Dadkhah, D.; Pourmoghaddas, M. Helicobacter pylori infection a risk factor for coronary heart disease? ARYA Atheroscler. 2012, 8, 5-8.

128. Chimienti, G.; Russo, F.; Lamanuzzi, B.; Nardulli, M.; Messa, C.; Di Leo, A.; Correale, M.; Giannuzzi, V.; Pepe, G. Helicobacter pylori is associated with modified lipid profile: Impact on Lipoprotein(a). Clin. Biochem. 2003, 36, 359-365. [CrossRef]

129. Lillich, F.F.; Imig, J.D.; Proschak, E. Multi-Target Approaches in Metabolic Syndrome. Front. Pharmacol. 2021, $11,554961$. [CrossRef] [PubMed]

130. Papamichael, K.X.; Papaioannou, G.G.; Karga, H.; Roussos, A.; Mantzaris, G.J. Helicobacter pylori infection and endocrine disorders: Is there a link? World J. Gastroenterol. 2009, 15, 2701-2707. [CrossRef]

131. Shmuely, H.; Wattad, M.; Solodky, A.; Yahav, J.; Samra, Z.; Zafrir, N. Association of Helicobacter pylori with coronary artery disease and myocardial infarction assessed by myocardial perfusion imaging. Isr. Med. Assoc. J. IMAJ 2014, 16, 341-346.

132. Kucukazman, M.; Yavuz, B.; Sacikara, M.; Asilturk, Z.; Ata, N.; Ertugrul, D.T.; Yalcin, A.A.; Yenigun, E.C.; Kizilca, G.; Okten, H.; et al. The Relationship Between Updated Sydney System Score and LDL Cholesterol Levels in Patients Infected with Helicobacter pylori. Dig. Dis. Sci. 2008, 54, 604-607. [CrossRef]

133. Ye, P.; Chen, H.W.L. Diagnosis and Treatment of Dyslipidemia, 2nd ed.; People's Military Medical Press: Beijing, China, 2013.

134. Pellicano, R.; Oliaro, E.; Fagoonee, S.; Astegiano, M.; Berrutti, M.; Saracco, G.M.; Smedile, A.; Repici, A.; Leone, N.; Castelli, A.; et al. Clinical and biochemical parameters related to cardiovascular disease after Helicobacter pylori eradication. Int. Angiol. 2009, 28, 469. 
135. Majka, J.; Róg, T.; Konturek, P.C.; Konturek, S.J.; Bielanski, W.; Kowalsky, M.; Szczudik, A. Influence of chronic Helicobacter pylori infection on ischemic cerebral stroke risk factors. Med. Sci. Monit. 2002, 8, CR675-CR684. [PubMed]

136. Jalalzadeh, M.; Ghadiani, M.H.; Mousavinasab, N. Association between Helicobacter pylori infection and body mass index, before and after eradication of infection in hemodialysis batients. J. Nephropathol. 2012, 1, 170-176. [CrossRef]

137. Gen, R.; Demir, M.; Ataseven, H. Effect of Helicobacter pylori Eradication on Insulin Resistance, Serum Lipids and Low-Grade Inflammation. South. Med. J. 2010, 103, 190-196. [CrossRef] [PubMed]

138. Lejawa, M.; Osadnik, K.; Osadnik, T.; Pawlas, N. Association of Metabolically Healthy and Unhealthy Obesity Phenotypes with Oxidative Stress Parameters and Telomere Length in Healthy Young Adult Men. Analysis of the MAGNETIC Study. Antioxidants 2021, 10, 93. [CrossRef] [PubMed]

139. Nazligul, Y.; Aslan, M.; Horoz, M.; Celik, Y.; Dulger, A.C.; Celik, H.; Erel, O. The effect on serum myeloperoxidase activity and oxidative status of eradication treatment in patients Helicobacter pylori infected. Clin. Biochem. 2011, 44, 647-649. [CrossRef]

140. Kim, Y.M.; Kim, J.-H.; Baik, S.J.; Chun, J.; Youn, Y.H.; Park, H. Sarcopenia and Sarcopenic Obesity as Novel Risk Factors for Gastric Carcinogenesis: A Health Checkup Cohort Study. Front. Oncol. 2019, 9, 1249. [CrossRef]

141. Dong, S.; Wang, Z.; Shen, K.; Chen, X. Metabolic Syndrome and Breast Cancer: Prevalence, Treatment Response, and Prognosis. Front. Oncol. 2021, 11, 989. [CrossRef]

142. Zhang, J.; Wu, H.; Wang, R. Metabolic syndrome and esophageal cancer risk: A systematic review and meta-analysis. Diabetol. Metab. Syndr. 2021, 13, 8. [CrossRef] [PubMed]

143. Hassen, L.J.; Lenihan, D.J.; Baliga, R.R. Hypertension in the Cardio-Oncology Clinic. Heart Fail. Clin. 2019, 15, 487-495. [CrossRef]

144. Doulberis, M.; Pierre, N.; Manzini, G.; Papaefthymiou, A.; Kountouras, J.; Klukowska-Rötzler, J.; Polyzos, S.; Srivastava, S.; Exadaktylos, A.; Knuchel, J.; et al. Helicobacter pylori-Related Metabolic Parameters and Premalignant Gastric Mucosa Histological Lesions in Swiss Bariatric Patients. Microorganisms 2021, 9, 1361. [CrossRef]

145. Kochi, T.; Shimizu, M.; Ohno, T.; Baba, A.; Sumi, T.; Kubota, M.; Shirakami, Y.; Tsurumi, H.; Tanaka, T.; Moriwaki, H. Enhanced Development of Azoxymethane-Induced Colonic Preneoplastic Lesions in Hypertensive Rats. Int. J. Mol. Sci. 2013, 14, 14700-14711. [CrossRef]

146. Kountouras, J.; Zavos, C.; Chatzopoulos, D.; Katsinelos, P. New Aspects of Helicobacter pylori Infection Involvement in Gastric Oncogenesis. J. Surg. Res. 2008, 146, 149-158. [CrossRef] [PubMed]

147. Warner, T.D.; Mitchell, J.A. Cyclooxygenases: New forms, new inhibitors, and lessons from the clinic. FASEB J. 2004, 18, 790-804. [CrossRef]

148. Slomiany, B.L.; Slomiany, A. Involvement of p38 MAPK-dependent activator protein (AP-1) activation in modulation of gastric mucosal inflammatory responses to Helicobacter pylori by ghrelin. Inflammopharmacology 2013, 21, 67-78. [CrossRef] [PubMed]

149. Slomiany, B.L.; Slomiany, A. Induction in gastric mucosal prostaglandin and nitric oxide by Helicobacter pylori is dependent on MAPK/ERK-mediated activation of IKK- $\beta$ and cPLA2: Modulatory effect of ghrelin. Inflammopharmacology 2013, 21, $241-251$. [CrossRef] [PubMed]

150. Grebowska, A.; Rechciński, T.; Bak-Romaniszyn, L.; Czkwianianc, E.; Moran, A.; Druszczyńska, M.; Kowalewicz-Kulbat, M.; Owczarek, A.; Dziuba, M.; Krzemińska-Pakuła, M.; et al. Potential role of LPS in the outcome of Helicobacter pylori related diseases. Pol. J. Microbiol. 2006, 55, 25.

151. Martinez-Gonzalez, J.; Badimon, L. Mechanisms Underlying the Cardiovascular Effects of COX-Inhibition: Benefits and Risks. Curr. Pharm. Des. 2007, 13, 2215-2227. [CrossRef]

152. Cipollone, F.; Cicolini, G.; Bucci, M. Cyclooxygenase and prostaglandin synthases in atherosclerosis: Recent insights and future perspectives. Pharmacol. Ther. 2008, 118, 161-180. [CrossRef]

153. Cipollone, F.; Fazia, M.L. COX-2 and Atherosclerosis. J. Cardiovasc. Pharmacol. 2006, 47, S26-S36. [CrossRef] [PubMed]

154. Li, W.; Zhao, J.; Song, L.; Chen, S.; Liu, X.; Wu, S. Combined effects of carotid plaques and hypertension on the risk of cardiovascular disease and all-cause mortality. Clin. Cardiol. 2020, 43, 715-722. [CrossRef]

155. Virdis, A.; Taddei, S. Endothelial Dysfunction in Resistance Arteries of Hypertensive Humans. J. Cardiovasc. Pharmacol. 2016, 67, 451-457. [CrossRef]

156. Wong, W.T.J.; Tian, X.Y.; Huang, Y. Endothelial Dysfunction in Diabetes and Hypertension. J. Cardiovasc. Pharmacol. 2013, 61, 204-214. [CrossRef]

157. Ye, J.; Wang, Y.; Wang, Z.; Liu, L.; Yang, Z.; Wang, M.; Xu, Y.; Ye, D.; Zhang, J.; Lin, Y.; et al. Roles and Mechanisms of Interleukin-12 Family Members in Cardiovascular Diseases: Opportunities and Challenges. Front. Pharmacol. 2020, 11, 129. [CrossRef]

158. Ye, J.; Wang, Y.; Wang, Z.; Lin, Y.; Liu, L.; Zhou, Q.; Wang, M.; Xu, Y.; Ye, D.; Zhang, J.; et al. Circulating IL-37 levels are elevated in patients with hypertension. Exp. Ther. Med. 2021, 21, 558. [CrossRef]

159. Shi, Y.; Liu, X.-F.; Zhuang, Y.; Zhang, J.-Y.; Liu, T.; Yin, Z.; Wu, C.; Mao, X.-H.; Jia, K.-R.; Wang, F.-J.; et al. Helicobacter pyloriInduced Th17 Responses Modulate Th1 Cell Responses, Benefit Bacterial Growth, and Contribute to Pathology in Mice. J. Immunol. 2010, 184, 5121-5129. [CrossRef]

160. Jafarzadeh, A.; Nemati, M.; Rezayati, M.-T. Circulating interleukin-27 levels in Helicobacter pylori-Infected patients with gastric or duodenal ulcers, independent of the bacterial cytotoxin-associated gene A virulence factor. J. Dig. Dis. 2011, 12, 302-307. [CrossRef] 
161. Davarpanah, E.; Jafarzadeh, A.; Nemati, M.; Bassagh, A.; Abasi, M.H.; Khosravimashizi, A.; Kazemipoor, N.; Ghazizadeh, M.; Mirzaee, M. Circulating concentration of interleukin-37 in Helicobacter pylori-Infected patients with peptic ulcer: Its association with IL-37 related gene polymorphisms and bacterial virulence factor CagA. Cytokine 2019, 126, 154928. [CrossRef]

162. Gu, J.; Wang, X.; Wang, L.; Zhou, L.; Tang, M.; Li, P.; Wu, X.; Chen, M.; Zhang, Y. Serum level of interleukin-35 as a potential prognostic factor for gastric cancer. Asia-Pac. J. Clin. Oncol. 2020, 17, 52-59. [CrossRef]

163. Wei, L.; Ding, H.-G. Relationship between Helicobacter pylori infection and nonalcoholic fatty liver disease. Medicine 2021, 100, e26706. [CrossRef] [PubMed]

164. Aneni, E.C.; Oni, E.T.; Martin, S.S.; Blaha, M.J.; Agatston, A.S.; Feldman, T.; Veledar, E.; Conçeicao, R.D.; Carvalho, J.A.; Santos, R.D.; et al. Blood pressure is associated with the presence and severity of nonalcoholic fatty liver disease across the spectrum of cardiometabolic risk. J. Hypertens. 2015, 33, 1207-1214. [CrossRef] [PubMed]

165. Ryoo, J.-H.; Suh, Y.J.; Shin, H.C.; Cho, Y.K.; Choi, J.-M.; Park, S.K. Clinical association between non-alcoholic fatty liver disease and the development of hypertension. J. Gastroenterol. Hepatol. 2014, 29, 1926-1931. [CrossRef]

166. Lorbeer, R.; Bayerl, C.; Auweter, S.; Rospleszcz, S.; Lieb, W.; Meisinger, C.; Heier, M.; Peters, A.; Bamberg, F.; Hetterich, H. Association between MRI-derived hepatic fat fraction and blood pressure in participants without history of cardiovascular disease. J. Hypertens. 2017, 35, 737-744. [CrossRef]

167. Qian, L.-Y.; Tu, J.-F.; Ding, Y.-H.; Pang, J.; Che, X.-D.; Zou, H.; Huang, D.-S. Association of blood pressure level with nonalcoholic fatty liver disease in nonhypertensive population. Medicine 2016, 95, e4293. [CrossRef]

168. Bonnet, F.; Gastaldelli, A.; Bars, F.P.-L.; Natali, A.; Roussel, R.; Petrie, J.; Tichet, J.; Marre, M.; Fromenty, B.; Balkau, B. Gammaglutamyltransferase, fatty liver index and hepatic insulin resistance are associated with incident hypertension in two longitudinal studies. J. Hypertens. 2017, 35, 493-500. [CrossRef]

169. Lau, K.; Lorbeer, R.; Haring, R.; Schmidt, C.O.; Wallaschofski, H.; Nauck, M.; John, U.; Baumeister, S.E.; Völzke, H. The association between fatty liver disease and blood pressure in a population-based prospective longitudinal study. J. Hypertens. 2010, 28, 1829-1835. [CrossRef]

170. Vasunta, R.-L.; Kesäniemi, Y.A.; Ylitalo, A.S.; Ukkola, O.H. High ambulatory blood pressure values associated with non-alcoholic fatty liver in middle-aged adults. J. Hypertens. 2012, 30, 2015-2019. [CrossRef] [PubMed]

171. Latea, L. Primary non-alcoholic fatty liver disease in hypertensive patients. Australas. Med. J. 2013, 6, 325-330. [CrossRef]

172. Singh, A.; Kumar, M.S.; Jaryal, A.K.; Ranjan, P.; Deepak, K.K.; Sharma, S.; Lakshmy, R.; Pandey, R.M.; Vikram, N.K. Diabetic status and grade of nonalcoholic fatty liver disease are associated with lower baroreceptor sensitivity in patients with nonalcoholic fatty liver disease. Eur. J. Gastroenterol. Hepatol. 2017, 29, 956-961. [CrossRef] [PubMed]

173. Li, J.; Verhaar, A.P.; Pan, Q.; de Knegt, R.J.; Peppelenbosch, M.P. Serum levels of caspase-cleaved cytokeratin 18 (CK18-Asp396) predict severity of liver disease in chronic hepatitis B. Clin. Exp. Gastroenterol. 2017, 10, 203-209. [CrossRef] [PubMed]

174. Bär, H.; Bea, F.; Blessing, E.; Watson, L.; Wende, P.; Kreuzer, J.; Kübler, W.; Jahn, L. Phosphorylation of cytokeratin 8 and 18 in human vascular smooth muscle cells of atherosclerotic lesions and umbilical cord vessels. Basic Res. Cardiol. 2001, 96, 50-58. [CrossRef] [PubMed]

175. Morrow, D.A.; Ridker, P.M. C-reactive protein, inflammation, and coronary risk. Med. Clin. N. Am. 2000, 84, 149-161. [CrossRef]

176. Todorovic, V.; Sokic-Milutinovic, A.; Drndarevic, N.; Micev, M.; Mitrovic, O.; Nikolic, I.; Wex, T.; Milosavljevic, T.; Malfertheiner, P. Expression of cytokeratins in Helicobacter pylori-Associated chronic gastritis of adult patients infected with cagA+ strains: An immunohistochemical study. World J. Gastroenterol. 2006, 12, 1865-1873. [CrossRef] [PubMed]

177. Patel, S.; Lawlor, D.A.; Ferreira, D.L.; Hughes, A.D.; Chaturvedi, N.; Callaway, M.; Day, C.; Sattar, N.; Fraser, A. The association of nonalcoholic fatty liver disease with central and peripheral blood pressure in adolescence. J. Hypertens. 2015, 33, 546-553. [CrossRef]

178. Racanelli, V.; Rehermann, B. The liver as an immunological organ. Hepatology 2006, 43, S54-S62. [CrossRef]

179. Houghton, D.; Zalewski, P.; Hallsworth, K.; Cassidy, S.; Thoma, C.; Avery, L.; Slomko, J.; Hardy, T.; Burt, A.D.; Tiniakos, D.; et al. The degree of hepatic steatosis associates with impaired cardiac and autonomic function. J. Hepatol. 2019, 70, $1203-1213$. [CrossRef]

180. Haukeland, J.W.; Damås, J.K.; Konopski, Z.; Løberg, E.M.; Haaland, T.; Goverud, I.; Torjesen, P.A.; Birkeland, K.; Bjøro, K.; Aukrust, P. Systemic inflammation in nonalcoholic fatty liver disease is characterized by elevated levels of CCL2. J. Hepatol. 2006, 44, 1167-1174. [CrossRef]

181. Potoupni, V.; Georgiadou, M.; Chatzigriva, E.; Polychronidou, G.; Markou, E.; Gakis, C.Z.; Filimidou, I.; Karagianni, M.; Anastasilakis, D.; Evripidou, K.; et al. Circulating tumor necrosis factor- $\alpha$ levels in non-alcoholic fatty liver disease: A systematic review and a meta-analysis. J. Gastroenterol. Hepatol. 2021, 36, 3002-3014. [CrossRef]

182. Satou, R.; Penrose, H.; Navar, L.G. Inflammation as a Regulator of the Renin-Angiotensin System and Blood Pressure. Curr. Hypertens. Rep. 2018, 20, 100. [CrossRef]

183. Yu, Y.; Cai, J.; She, Z.; Li, H. Insights into the Epidemiology, Pathogenesis, and Therapeutics of Nonalcoholic Fatty Liver Diseases. Adv. Sci. 2018, 6, 1801585. [CrossRef]

184. Kountouras, J.; Boziki, M.; Polyzos, S.A.; Katsinelos, P.; Gavalas, E.; Zeglinas, C.; Tzivras, D.; Romiopoulos, I.; Giorgakis, N.; Anastasiadou, K.; et al. Impact of reactive oxygen species generation on Helicobacter pylori-Related extragastric diseases: A hypothesis. Free. Radic. Res. 2017, 51, 73-79. [CrossRef] 
185. Dongiovanni, P.; Stender, S.; Pietrelli, A.; Mancina, R.M.; Cespiati, A.; Petta, S.; Pelusi, S.; Pingitore, P.; Badiali, S.; Maggioni, M.; et al. Causal relationship of hepatic fat with liver damage and insulin resistance in nonalcoholic fatty liver. $J$. Intern. Med. 2017, 283, 356-370. [CrossRef] [PubMed]

186. Polyzos, S.A.; Kountouras, J. Helicobacter pylori infection and nonalcoholic fatty liver disease: Time for large clinical trials evaluating eradication therapy. Helicobacter 2019, 24, e12588. [CrossRef] [PubMed]

187. Ferrara, D.; Montecucco, F.; Dallegri, F.; Carbone, F. Impact of different ectopic fat depots on cardiovascular and metabolic diseases. J. Cell. Physiol. 2019, 234, 21630-21641. [CrossRef] [PubMed]

188. Schwimmer, J.; Johnson, J.S.; Angeles, J.E.; Behling, C.; Belt, P.H.; Borecki, I.; Bross, C.; Durelle, J.; Goyal, N.P.; Hamilton, G.; et al. Microbiome Signatures Associated With Steatohepatitis and Moderate to Severe Fibrosis in Children With Nonalcoholic Fatty Liver Disease. Gastroenterology 2019, 157, 1109-1122. [CrossRef]

189. Tripathi, A.; Debelius, J.; Brenner, D.A.; Karin, M.; Loomba, R.; Schnabl, B.; Knight, R. The gut-liver axis and the intersection with the microbiome. Nat. Rev. Gastroenterol. Hepatol. 2018, 15, 397-411. [CrossRef] [PubMed]

190. Kountouras, J.; Zavos, C.; Polyzos, S.A.; Deretzi, G. Potential impact of Helicobacter pylori-Related human $\beta$-defensin-1 on hepatic encephalopathy and neurodegeneration. Ann. Gastroenterol. 2016, 29, 99.

191. Sharifnia, T.; Antoun, J.; Verriere, T.G.C.; Suarez, G.; Wattacheri, J.; Wilson, K.T.; Peek, R.M.P., Jr.; Abumrad, N.N.; Flynn, C.R. Hepatic TLR4 signaling in obese NAFLD. Am. J. Physiol.-Gastrointest. Liver Physiol. 2015, 309, G270-G278. [CrossRef]

192. Yola, I.M.; Moser, C.; Duncan, M.S.; Schwedhelm, E.; Atzler, D.; Maas, R.; Hannemann, J.; Böger, R.H.; Vasan, R.S.; Xanthakis, V. Associations of circulating dimethylarginines with the metabolic syndrome in the Framingham Offspring study. PLoS ONE 2021, 16, e0254577. [CrossRef] [PubMed]

193. Dogru, T.; Genc, H.; Tapan, S.; Ercin, C.N.; Ors, F.; Aslan, F.; Kara, M.; Sertoglu, E.; Bagci, S.; Kurt, I.; et al. Elevated asymmetric dimethylarginine in plasma: An early marker for endothelial dysfunction in non-alcoholic fatty liver disease? Diabetes Res. Clin. Pract. 2012, 96, 47-52. [CrossRef] [PubMed]

194. Persico, M.; Masarone, M.; Damato, A.; Ambrosio, M.; Federico, A.; Rosato, V.; Bucci, T.; Carrizo, A.; Vecchione, C. Non alcoholic fatty liver disease and eNOS dysfunction in humans. BMC Gastroenterol. 2017, 17, 35.

195. Li, N.; Zhang, G.-W.; Zhang, J.-R.; Jin, D.; Li, Y.; Liu, T.; Wang, R.-T. Non-alcoholic fatty liver disease is associated with progression of arterial stiffness. Nutr. Metab. Cardiovasc. Dis. 2015, 25, 218-223. [CrossRef] [PubMed]

196. Assali, A.; Ghayour-Mobarhan, M.; Sahebkar, A.; Hassani, M.; Kasaian, J.; Tatari, F.; Moohebati, M.; Paydar, R.; Oladi, M.; Esmaeili, H.A.; et al. Association of angiotensin II type 1 receptor gene A1166C polymorphism with the presence of diabetes mellitus and metabolic syndrome in patients with documented coronary artery disease. Eur. J. Intern. Med. 2011, 22, $254-261$. [CrossRef]

197. Sugimoto, M.; Ohno, T.; Graham, D.Y.; Yamaoka, Y. Helicobacter pylori outer membrane proteins on gastric mucosal interleukin 6 and 11 expression in Mongolian gerbils. J. Gastroenterol. Hepatol. 2011, 26, 1677-1684. [CrossRef] [PubMed]

198. Li, L.; Liu, H.; Hu, X.; Huang, Y.; Wang, Y.; He, Y.; Lei, Q. Identification of key genes in non-alcoholic fatty liver disease progression based on bioinformatics analysis. Mol. Med. Rep. 2018, 17, 7708-7720. [CrossRef]

199. Musso, G.; Saba, F.; Cassader, M.; Paschetta, E.; De Michieli, F.; Pinach, S.; Framarin, L.; Berrutti, M.; Leone, N.; Parente, R.; et al. Angiotensin II Type 1 Receptor rs5186 Gene Variant Predicts Incident NAFLD and Associated Hypertension: Role of Dietary Fat-Induced Pro-Inflammatory Cell Activation. Am. J. Gastroenterol. 2019, 114, 607-619. [CrossRef]

200. Li, Y.; Xu, H.; Wu, W.; Ye, J.; Fang, D.; Shi, D.; Li, L. Clinical application of angiotensin receptor blockers in patients with non-alcoholic fatty liver disease: A systematic review and meta-analysis. Oncotarget 2018, 9, 24155-24167. [CrossRef] 